\title{
A European public prosecutor: potential and pitfalls
}

\author{
Marianne L. Wade
}

Published online: 14 March 2013

(C) The Author(s) 2013. This article is published with open access at Springerlink.com

\section{Introduction}

The idea of a European Public Prosecutor (hereinafter an EPP) is a conundrum. Whilst for at least 15 years, experts tasked with the question of how to better protect the financial interests of the EU have considered it a logical next step, ${ }^{1}$ others react to it as a rider of the Apocalypse for European nation states. British citizens may famously ponder the content of their unwritten Constitution but are equipped with the knowledge that it features protection against joining the Euro and an EPP. ${ }^{2}$ Perhaps only those unfamiliar with UK politics will express astonishment that a Constitution can leave human rights seemingly less well protected than a means of payment and freedom from a judicial office within a system we have entrusted with a mechanism to arrest and surrender citizens. Many of those who live and work in the land which Montesqieu once heaped with praise also share this astonishment and question this state of affairs which sees introducing a new currency or a supra-national prosecutor beyond the reach of Parliamentary power, not, however, the ability to provide for citizens to be detained for 90 days without charge. If the United Kingdom Government must be viewed as expressing its scepticism in a radical manner, it can nevertheless not be said to stand alone in some of its concerns. The question of an EPP is divisive. The EU is soon set to discover just how strongly.

With the creation of a separate Directorate-General for Justice (splitting the former DG Justice, Freedom, Security) on the 1 st of July $2010,{ }^{3}$ the post- Lisbon Treaty

\footnotetext{
${ }^{1}$ See the Corpus Juris study [28, 108] and the Green Book by the European Commission [8]. Reactions of British press and Government are reported by Prof. John Spencer [29].

${ }^{2}$ Through the most likely insurmountable referendum requirement imposed by the European Union Act, 2011 , c. 11 , s. 6 .

${ }^{3}$ See webpage http://ec.europa.eu/justice/mission/index_en.htm (last download 27.07.2012). Since September 2012 see also http://ec.europa.eu/justice/criminal/index_en.htm (last download 21.10.2012).

M. L. Wade $(\bowtie)$

Institute of Judicial Administration, School of Law, University of Birmingham,

Edgbaston Birmingham, West Midlands B15 2TT, UK

e-mail: m.1.wade@bham.ac.uk

M. L. Wade

University of Goettingen, Goßlerstraße 5, 37073 Göttingen, Germany
} 
European Commission was structured to emphasise this area of work in a novel manner. From the very beginning, the vigorous new Commissioner - Vice-President Viviane Redding, set out an ambitious work-plan which foresees the tabling of a proposal for a European Public Prosecutor's Office (hereinafter EPPO) for $2013 .^{4}$

Any proposal to create an EPPO will be viewed critically as a potential encroachment upon the power of the sovereign EU member states to organise and control the systems which administer criminal justice upon their territory a power usually held closely and dearly by the Parliaments of member states themselves. ${ }^{5}$ This potentially revolutionary step forward comes at a time where such developments will inevitably, and not entirely illegitimately, be eyed suspiciously. The past years have seen the criminal justice related work of the EU advance considerably with legislative initiatives for example to enhance the rights of victims[1; p. 38, 43] and against phenomena such as organised crime and terrorism [2-4]. In this way the EU has become established as an actor in the criminal justice arena. The vast majority of member states argued only a few years ago that the EU was in fact no more than their elected forum for multi-lateral action and that no constitutional or broader governance consequences flowed from this. ${ }^{6}$ The cases of Pupino, ${ }^{7}$ concerning the environmental directive ${ }^{8}$ and ship-source pollution ${ }^{9}$ demonstrated this belief to have been false. Furthermore, the imbalance of actions taken which as agreed by the member states have almost purely favoured the punitive efficiency of criminal justice systems - has been subject to considerable criticism. ${ }^{10}$ Nevertheless the Lisbon Treaty enhanced the EU's potential as a criminal justice actor also via article 86 TFEU providing a legal basis for an EPPO.

\footnotetext{
${ }^{4}$ This constitutes an intent to use the newly provided legal basis for such an office to be found in the European Treaties since the Treaty of Lisbon, article 86 TFEU. Like other criminal justice-related norms, this regulation is an adoption straight from the failed Constitutional Treaty-see Herlin-Karnell, E. [30;p.1] and van den Wyngaert, C.[31;p.204 et seq],. One can speculate how such a controversial legal norm could survive a failure such as the Constitutional Treaty; optimists might suggest this as indicative of some notion of agreement amongst even critical member states, that there might be good reasons for such an office-so e.g. Zwiers, M. [32;p.6]; whilst cynics might reflect that those critics were distracted by even greater controversies. The UK House of Lords for instance, recommended the abolition of this provision-see House of Lords Select Committee on the European Union [33;para. 93]. For one account of how it came to be included in the draft Treaty see House of Lords Select Committee on European Scrutiny [34;paras.7282].

${ }^{5}$ See Wade [35], Part III.I.C. For an analysis of sovereignty in this particular context see van den Wyngaert, C. $[31 ;$ p. 229 et seq.].

${ }^{6}$ See e.g. the member states' submissions to Commission of the European Communities v Council of the European Union, case C-176/03, Judgment of the Court (Grand Chamber), 13 September 2005.

${ }^{7}$ Criminal proceedings against Maria Pupino, C-105/03, Judgment of the Court (Grand Chamber), 16 June 2005.

${ }^{8}$ Commission of the European Communities v Council of the European Union, case C-176/03, Judgment of the Court (Grand Chamber), 13 September 2005.

${ }^{9}$ Commission of the European Communities v Council of the European Union, case C-440/05, Judgment of the Court (Grand Chamber), 28 June 2007.

${ }^{10}$ Even by former Commission Vice-President Frattini, who expressed his concern that the EU had developed an Area of Security although its mandate was to develop one of Freedom, Security and Justice upon the occasion of a German Presidency conference on the failed Framework Decision of Fundamental Rights in Criminal Proceedings, 20.02.2007, Berlin, see http://www.bmj.bund.de/enid/ 68e692448b67b5925478ba1197305426,33d0e45f7472636964092d0933303334/Deutsche_EUPraesidentschaft_2_7/Verfahrensrechte_im_Strafverfahren_18q.html.
} 


\section{Suggestions for a European public prosecutor}

The driving force behind suggestions that an EPPO should be created is invariably the efficient protection of the financial interests of the EC and now the EU. This proposal can be seen as the logical conclusion of discussions which began with the famous Greek Maize case. ${ }^{11}$ In this cornerstone judgement the European Court of Justice ruled that the member states are under an obligation to protect the European Communities' interests by means equivalent to those which it protects its own respective interests. $^{12}$

In the area of financial interests the main problem may be regarded as fraud. ${ }^{13}$ Defrauding the public purse is an action all member states qualify as criminal within their own system [5, 110; p.44 and 112; vor $\S 263$ para. 51 et seq.]. The argument is thus, quite naturally, that fraud against the European Communities/Union (i.e. the European public purse), should in parallel be pursued as criminal. The member states' have, however, consistently refused to endow the institutions and agencies of the EC/ EU with criminal justice powers. ${ }^{14}$ Since 1999, the European Commission houses an anti-fraud unit (OLAF), which has powers to conduct or perhaps more correctly to initiate and co-ordinate administrative investigations. ${ }^{15}$ The EU remains entirely dependent upon then finding a member state prosecution service willing and able to take over responsibility for a case and bring it to court in order to secure criminal convictions and punishment for such offences. ${ }^{16}$

OLAF have long maintained that national prosecution services often face enormous challenges when called upon to prosecute offences against the financial interests of the EU [6;p.25]. Such cases are often complex and may require consideration of acts committed or evidence found in one or more other member states. The intricate financial regulations of the EU are also often new to prosecutors. Furthermore, national prosecution services may be so overloaded [7; p.5] in their daily business that the will to take over or pursue the prosecution of crimes against another "sovereign" involving the breach of complex "foreign" rules, may be lacking.

Calls for the establishment of an EPPO have been and are in essence the call for a specialist service dedicated to ensuring such cases of complex and large-scale fraud, etc. are brought to justice [8;p.12, 32, 37;p.13]. This restrictive remit is clearly expressed in article 86 (1)TFEU which reads: "in order to combat crimes affecting the financial interests of the Union, the Council, by means of regulations adopted in accordance with a special legislative procedure, may establish a European Public Prosecutor's Office from Eurojust" and further states: "The European Public Prosecutor's Office shall be responsible for investigating, prosecuting and bringing to judgment ... the perpetrators of, and accomplices in, offences against the Union's financial interests ... It shall exercise the functions of prosecutor in the competent courts of the Member States in relation to such offences" (article 86 (2) TFEU).

\footnotetext{
${ }^{11}$ Case 68/88 Commission v Greece [1989] ECR 2965.

12 Case 68/88 Commission v Greece [1989] ECR 2965, paras. 23-25

${ }^{13}$ For an explanation of possible modi see Spencer, J. [29;p.3 et seq.].

${ }^{14}$ As for example in the competition law enforcement area.

15 Sometimes leaving them with very limited reach - see Vervaele, J. A.E. [36; p.180]. See also [104].

${ }^{16}$ Report of the European Anti-Fraud Office [37; p.54]. A dependency also consciously retained for Eurojust-See van den Wyngaert, C. [31;p.224 et seq. And 109].
} 
Given the controversy surrounding this potential office, perhaps surprisingly article 86 (4), however also states: "the European Council may, at the same time or subsequently, adopt a decision amending paragraph 1 in order to extend the powers of the European Public Prosecutor's Office to include serious crime having a cross-border dimension and amending accordingly paragraph 2 as regards the perpetrators of, and accomplices in, serious crimes affecting more than one Member State. The European Council shall act unanimously after obtaining the consent of the European Parliament and after consulting the Commission" (for further analysis see [111 and 113]).

The Treaty of Lisbon has therefore also given birth to a provision which incorporates a broader vision of what an EPPO might do. This perhaps reflects the multi-faceted background of criminal justice work tackled previously within the 3rd pillar of the EU [10;p.193, 11;p.449 et seq.]. It is furthermore in line with other provisions of the TFEU which foresee EU criminal justice work more broadly. ${ }^{17}$ Article 86 (4) clearly views an EPPO as a potential figure in tackling offences requiring trans-/supra-national co-operation. This EPPO would thus be a descendant of the third pillar which the member states previously utilised to work together in fighting certain crimes, viewed as threatening the Union as a whole, deserving or indeed requiring common action [12-14]. The prime example of the last decade is terrorism. Trafficking offences and currency counterfeiting provide further examples of offences pursued through common action by all member states or a number of Schengen ${ }^{18}$ or Eurozone member states respectively. Such activity is reflective of the EU's unique position as an instance of governance incorporating as it does such developments as the border-check free Schengen area and the Euro.

The Commission is currently, however, exercising great caution to ensure debate about an EPPO remains firmly related to the offences against the financial interests of the Union. ${ }^{19}$ Any expanded discussion at this point would likely heighten controversy and resistance to such an institution. It is interesting to note the difference between the drafting of article 86 TFEU and the current proposal preparation as tellingly symptomatic of EU workings. Depending upon the Zeitgeist, institutional development is pushed by very different factors. At the moment Article

\footnotetext{
${ }^{17}$ Article 83 (1) TFEU defines the areas of interest as those "of particularly serious crime with a crossborder dimension resulting from the nature or impact of such offences or from a special need to combat them on a common basis" before defining these more closely as "terrorism, trafficking in human beings and sexual exploitation of women and children, illicit drug trafficking, illicit arms trafficking, money laundering, corruption, counterfeiting of means of payment, computer crime and organised crime" but also adding "On the basis of developments in crime, the Council may adopt a decision identifying other areas of crime that meet the criteria specified in this paragraph. It shall act unanimously after obtaining the consent of the European Parliament."

18 The multi-lateral Schengen Agreement was signed by 25 EU member states, Iceland, Norway, Switzerland and Lichtenstein (though Great Britain, Denmark, and Ireland have opted out of certain categories of co-operation). In 2003, it was integrated into the law or acquis of the European Union, and thus falls within the ambit of the European Court of Justice. It is best known for abolishing internal border controls between countries in Western Europe. For an introduction, see, e.g., House of Lords Select Committee [38]; See also Wade [39].

19 Thus the clear mandate given, e.g. to the academic group developing model procedural rules-see http:// www.eppo-project.eu/index.php/Home. This work was presented at a recent conference: A Blueprint for the European Public Prosecutor's Office? EU model rules of criminal procedure in Luxembourg on the 1315th June 2012.
} 
86 is the tool of those seeking to protect a new and badly protected victim; the EU, via criminal justice. Were circumstances similar to those when the Constitutional Treaty was drafted (for that was the genesis of what is now article $86^{20}$ ), we would likely see a very different debate focusing upon terrorism and possibly involving quite different institutional representatives. ${ }^{21}$ Article 86 contains two very different embryos: one bears the EPPO as the EU's prosecutor - protecting this entity's interests. The other also serves European interest but can perhaps be seen as the logical pinnacle of member state trans-national co-operation. The potential for both of these will be explored in what follows although it is only the former which is currently subject to discussion.

\section{Determining whether we need an EPPO}

As has become clear, the creation of an EPPO is a legally interesting matter and an issue of the greatest political sensitivity. This is reflected in the legal provision made thus far which represents no more than an initial seed. In its recent consultation of practitioners as to the potential benefits an EPPO might have, the Commission was careful to make no mention of the expansive possibilities of article $86(4) .^{22}$

Amongst the legal wranglings and political hyperbole of this debate, it is easy to lose sight of what certainly should be the central issue: the question why we might need a European public prosecutor? It is this case the European Commission currently seeks to make in relation to the Union's financial interests. The member states are unquestionably alert to issues of EU "competence creep" and extremely sensitive to any notion of European institutions assuming powers best exercised by their own authorities. ${ }^{23}$ Anyone genuinely interested in the creation of an EPPO would be unwise to risk debate straying from core discussion of what problems are faced and how an EPPO could provide solutions. Only if the member states accept such arguments and an institution of this kind as in line with the principle of subsidiarity, ${ }^{24}$ can an EPPO proposal succeed. Extensive consultations of practitioners are already underway and are set to form the background of any initiative tabled by the Commission in combination with the requisite impact assessment recently assigned to a large management consultancy firm. $^{25}$

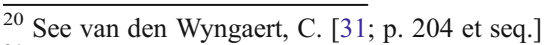

${ }^{21}$ See e.g. this demand by Roma [40]. Only 4 years ago, a leading commentator expressed the expectation that we may see an European Public Prosecutor with jurisdiction for terrorism-related offences sooner rather than later - Vervaele, J. [41].

${ }^{22} \mathrm{See}<\mathrm{http}: /$ ec.europa.eu/justice/newsroom/criminal/opinion/120307_en.htm $>$ for further information on the consultation and its aims.

${ }^{23}$ Thus note the cautious approach of the German government in reaction to the critical Bundestag and Bundesrat [42].

${ }^{24} \mathrm{~A}$ topic of heated discussion since the inter-governmental conference which proposed the draft Constitutional Treaty - see e.g. White, S. [43; p.53]

${ }^{25}$ Thus the consultation mentioned in footnote 23 was followed by a meeting of the Prosecutor's General in Brussels in June 2012.
} 


\section{The EuroNEEDS project}

With the aim of exploring the potential benefits to be gained from and problems associated with a European public prosecutor, this paper outlines preliminary results of the EuroNEEDs study. This independent academic study was carried out by the author at the Max Planck Institute for Foreign and International Criminal Law. It was co-financed by the Hercule Programme of the European Commission and only feasible due to the work of a large project team. ${ }^{26}$

The study was visualised on the basis of the Hague programme, viewing the European Union as a single area of freedom, security and justice; developments within European criminal law as serving the purpose of providing for this. The core hypothesis of the study is that a European area of freedom, security and justice centrally has two requirements clearly matched to the two embryonic strands of article 86 TFEU identified above:

i. that the interests of that Union are adequately protected throughout the Union ${ }^{27}$ and that

ii. the national borders within the Union pose no impediment to the successful prosecution (in its broadest sense ${ }^{28}$ ) of crime.[15; p.11]

Requirement i. acknowledges that the area of freedom, security and justice of the European Union must consider and protect the assets and institutions of what was previously known as the European Communities and ensure that offences against the Union's interests are equally and adequately protected throughout the Union. The EuroNEEDs study set out to establish in how far this is the case relating to the Union's financial interests. Given the intensity of debate surrounding this subject, especially in this the post-Lisbon era, it was considered necessary to focus also upon an evaluation of related reform and improvement proposals, in particular the potential for a European public prosecutor.

Requirement ii addresses above all, the area of cross-border cooperation which has become of central political importance since the Tampere Council. ${ }^{29}$ The study aimed

\footnotetext{
${ }^{26}$ Consisting of: Lorena Bachmeier-Winter, Stefan Braum, Zoran Buric, Alexia Couccoullis, Valentina Covolo, Zlata Durdevic, Ákos Farkas, Birgit Feldtmann, Jaroslav Fenyk, Jaan Ginter, Adam Gorski, Tricia Howse, Robert Kert, Michiel Luchtman, Jussi Ohisalo, Anna Ondrejova, Andrzej Sakowicz, Valeria Scalia, Rosaria Sicurella, Patrick De Wolf, Helen Xanthaki, Sophie Zietek, Josef Zila who respectively provided expertise and conducted the interviews in their domestic jurisdiction.

The project was co-managed in Freiburg by the author and Ellen Weaver. The project team was supported by student assistants who came and went in the course of the study: Daniel Hannemann, Mika Kremer, Nevena Kostova, Jan Philipp Köster, Philip Ridder and, especially, Sarah Schultz. Many thanks are due to all

${ }^{27}$ As required by the famous Greek Maize judgment C-68/88 (Commission v Greece), see especially paragraph 24 of the judgment of 21st September 1989.

${ }^{28}$ Prosecution is meant and the word prosecutor used in a Continental sense meaning that all steps towards lodging a criminal charge are indicated. In other words, investigative work is explored purely as part of the broader prosecution process.

${ }^{29}$ The Tampere Council of 1999, which launched the principle of mutual recognition in the European criminal justice areas, can in many ways be regarded as the birthplace of European criminal justice as we know it today [44;pp 33-37]. The principle of mutual recognition was the key feature of the European Arrest Warrant - regarded as the most successful European criminal justice mechanism introduced thus far $[45 ;$ p.3] - and is declared the cornerstone of co-operation in criminal matters by the Lisbon Treaty - see article 82.
} 
to evaluate how well the mechanisms introduced by the European Union to date have contributed to ensuring borders pose no significant problems to criminal justice [16]. The study also considered reform proposals and further mechanisms to improve the functioning of trans-national prosecution.

The EuroNEEDs study thus identifies two areas of criminality as of legitimate "European" criminal justice interest namely crimes against (the financial interests of) the EU and cross-border crime. In the EuroNEEDs analysis and what follows these are referred to as European crimes being dealt with in European cases; intended to indicate their scale and nature as meaning that they should be viewed of as equal concern to any European citizen and tax payer. They are referred to as financial interest and transnational crimes respectively. These are crimes likely to be combatted successfully only if a criminal justice perspective beyond the traditional, nationally-bound is assumed.

It may plausibly be argued that the EU - as a supra-national instance - has interests beyond the collective concerns of the member states. In relation to crimes against its budget, the EU's interests may, in some cases, even be contrary to those of member states. In relation to cross-border crime, the EU has sought to make provision for comprehensive investigation and prosecution of these, ${ }^{30}$ often significantly boosting the reach of member state action to ensure a different quality of investigation and prosecution. The legitimacy of EU action in such contexts - as opposed to work by any other institution negotiating trans-national treaties - is lent particularly by the specific nature of the EU. As a supra-national governance level providing for the free movement of goods, persons, products and capital [17], it plausibly facilitates crime of different sorts. The member states and EU institutions are committed to ensuring these freedoms are not abused [18]. The EuroNEEDs project design consequently features a presumption that the EU bears a particular responsibility for combatting crimes it facilitates as a community; it must seek to protect the legitimacy and to avoid the abuse of its fundamental principles.

It should be expressly stated that this study views the work of defence lawyers as central to criminal justice; thus the study also investigated in how far the jurisdictional borders within the Union may impede defence work as usually foreseen within criminal justice systems. As it is not key to the topic at hand, these study results are not explored in any detail here. However, the study results clearly indicate that any development of prosecutorial structures should be accompanied by careful consideration of necessary defence evolution.

EuroNEEDs methodology Regarding, as it did, these issues as a European matter, the EuroNEEDs study sought to ensure the results gained are truly European. It was therefore carried out as a comparative study; posing its question in different national and supra-national contexts. Interviews were conducted with 132 prosecutors and 60 defence lawyers in 17 EU member states and Croatia ${ }^{31}$ as well as practitioners working within OLAF, at Europol and Eurojust. ${ }^{32}$ Interview partners were selected

\footnotetext{
${ }^{30}$ E.g. via Europol analysis, Eurojust support, joint investigation teams etc.

${ }^{31}$ Currently an accession country and set to become the 28th EU member state on the $1^{\text {st }}$ of January 2013.

${ }^{32}$ In what follows, Europol, Eurojust and OLAF are described in this way regarded as criminal justice related institutions located at the European level-for a precise analysis of Eurojust's status see Suominen, A,[46]; also van den Wyngaert, C. [31;p.207 et seq.]; for OLAF see Xanthaki, H. [47]
} 
as practitioners dealing with cases of offences against the EU budget on the one hand and trans-national organized crime (if necessary specialized in human trafficking, drug smuggling and corruption) on the other. ${ }^{33}$ In reality, such clean differentiation was not always possible amongst national prosecutors. Study results are presented to demonstrate the results from all those interviewed as well as broken down into offences against the financial interests of the EU (hereinafter financial interests) and trans-national crime expert groups. These specialist groups contain only those with relevant expertise exclusively in that area meaning that their statements can be taken as relating solely to that particular group of crimes. In particular in relation to interviewees with financial interest expertise, this narrowed the sample considerably; many prosecutors with expertise in this field also have experience dealing with other trans-national crime and so their comments are presented as equally applicable to both crime categories.

Practitioners were questioned as to the challenges they face when investigating and prosecuting cases with a European dimension. These were defined as cases which either victimised the European Union (in particular via its budget either directly or indirectly) or are trans-national crimes of concern to the EU (as defined by EU instruments). ${ }^{34}$ In relation to the investigation and prosecution of such offences, practitioners were further asked which of the instruments and agencies available to them at the European level they currently use, whether they feel anything is lacking and their attitudes to particular reform possibilities, including the EPPO, were explored. They were questioned in accordance with a standardized questionnaire (designed specifically for each sub-group: national prosecutors, defence lawyers, practitioners working in supra-national settings. The first and third featured much common ground). Interviewees were, however, always free to express their own ideas and thoughts in further comments. A qualitative analysis of this wealth of additional material is currently underway. The interviews were conducted in the relevant practitioners' native tongue though questionnaires were usually provided to interviewees in English in advance. ${ }^{35}$ Interviewers were briefed as to the purpose of the study and the questionnaires discussed in detail with them at a preliminary project workshop to ensure interviews were as uniform as possible.

\footnotetext{
${ }^{33}$ For a detailed description of methodology, interviewee selection process, limitations, etc. please see the preliminary report submitted to the European Commission: Wade [23].

${ }^{34}$ Most comprehensively see article 83 (1) TFEU which states: "in the areas of particularly serious crime with a cross-border dimension resulting from the nature or impact of such offences or from a special need to combat them on a common basis" defining these more closely as "terrorism, trafficking in human beings and sexual exploitation of women and children, illicit drug trafficking, illicit arms trafficking, money laundering, corruption, counterfeiting of means of payment, computer crime and organised crime." On the clarity provided by this see House of Lords [48; pp.142-143]. Mitsilegas notes that whilst this is an expansion of Union/Community competence in the substantive criminal law field, it is a narrowing of scope in comparison to previous third pillar activities - see Mitsilegas, V. [49;p.108].

35 The questionnaire for national prosecutors was designed in discussion with all project partners who also attended a seminar to ensure all interviewers operated asking questions based on the same premise. Interviews were usually recorded using digital voice recording devices. Where, exceptionally, interviewees declined the recording of conversations, detailed notes were made during and post interview. Interview results were entered by the interviewer - a project partner native in the respective member state with expertise in European criminal law - into an internet survey tool.
} 
As the vast majority of interviewees were prosecutors in continental and thus inquisitorial criminal justice systems, this sees them in charge of the investigation as well as prosecutorial decisions. ${ }^{36}$ The questionnaire was not adapted for common law jurisdictions in which this is not formally the case as research findings indicate a factually similar role for senior prosecutors there when working the kinds of cases forming the study focus. Even though the law does not require their participation in the same way, English and Welsh prosecutors for example are consulted and play similar roles to their continental counterparts in investigations into serious crime. $^{37}$

The questionnaires and ensuing interviews were clearly based upon the presumptions outlined above and thus prominently marked by the following premises:

1) That cases of criminal offences arise within the territory of the European Union which affect interests fittingly described as European. This is clearly the case where property and legal interests of the Union itself suffer damage. Furthermore, a European interest is recognized in the effective combatting of certain trans-national crimes as recognized by the member states by their use of the third pillar instruments in the decade prior to the Lisbon Treaty entering into force.

2) As the enforcement of laws against such offences still falls to the national authorities of the member states, they face particular challenges in investigating and prosecuting them. This is because such cases certainly involve the breach of laws from another jurisdiction (EU or foreign law) and are often of a geographical scope beyond the jurisdiction of one member state.

The existence of Europol, Eurojust and OLAF and indeed instruments such as the European Arrest Warrant (EAW) [12] and the gestating European Investigation Order (EIO) $[19,106]$ can be taken as evidence that the member states recognize this.

Interviewees were on the whole accepting of the first premise though the meaning attached to this naturally varied. Regarding the second premise, a minority of interviewees, as we shall see, felt that given the institutions and instruments made available to them via third pillar action, this was no longer true. The vast majority, however, testified that this is, and to a certain extent always will be, the case.

If the EuroNEEDS study is to lend any credence to the idea of an EPPO, clearly this would require that it identified problems faced by practitioners in dealing with European cases for which an EPPO could potentially provide solutions. ${ }^{38}$ These are the two aspects explored in the following: Problems faced

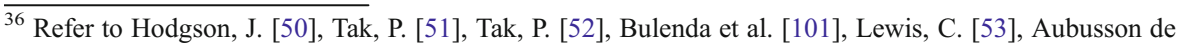
Cavarlay, B. [54], Elsner, B., Peters, J. [55], Blom, M., Smit, P. [56], Zila, J. [57] Turković, K. [58], Róth, E.[59], Aebi, M.F., Balcells, M. [60] Gilliéron, G., Killias, M. [61], Hakeri, H. [62].

${ }^{37}$ See Wade [63;p. 108].

${ }^{38}$ This is, of course, the first argument made against an EPP - see e.g. Donoghue [64; p.11] One leading commentator already declared it the theoretically more efficient option in 2005 - See van den Wyngaert, C. [31; p.226].
} 
by national prosecutors when investigating and prosecuting European crimes and the potential of an EPP to solve them

Prosecution of crime currently unpunished The most obvious problem calling for further action and indeed the one cited by the Commission justifying their calls for an EPPO, is the assertion that cases of serious crime currently go unprosecuted. ${ }^{39}$

Interviewees tended to be very hesitant in answering questions concerning the current criminal justice response rate to European crimes. Above all, they highlighted the lack of knowledge as to the dark number, i.e. extent of crime altogether. Practitioners at Eurojust, Europol and OLAF (labelled supra-national interviewees in the statistical analysis) similarly were for the most part unwilling to speculate. $27 \%$ (8 of 30) supra-national interviewees were prepared to answer the relevant question; all stating that only a minority of crimes against the financial interests of the EU are successfully investigated and prosecuted. Of the 23 asked, ${ }^{40} 22 \%$ (5) stated that a majority of trans-national crimes are successfully investigated and prosecuted whilst $9 \%$ (2) claimed this was only a minority. The majority of interviewees felt unable to answer these questions.

It is interesting to note that interviewees remained reticent in discussing criminal justice "success" rates, also in relation to their area of expertise. One might wish to note that those who did provide a response for crimes against the financial interests of the EU, clearly indicate only a minority of crime is being dealt with. None of these specialists asserted that the majority of crimes were being dealt with. This is in line with claims consistently made by the Commission. ${ }^{41}$

Interviewees were, however, far more willing to be drawn on the trends in such crimes with practitioners indicating that European crimes are on the increase. The study thus shows $60 \%$ of practitioners working in supra-national institutions stating that they estimate European crimes being on the increase and $10 \%$ that their rate is stable (with the remaining $30 \%$ not feeling able to give an estimate). These $10 \%$ stemmed exclusively from practitioners who are financial interest experts. The analysis of answers related to financial interests crime sees these practitioners (who estimate European crimes against the financial interests of the EU as remaining stable) forming $21 \%$. In this specific context $50 \%$ of interviewees were convinced this type of crime is on the increase with $29 \%$ of interviewees feeling unable to provide an estimate. No one asserted a decrease in criminal activity.

\footnotetext{
${ }^{39}$ See this suggested most recently in the Commission (DG Justice)'s consultation on the protection of the European Union's financial interests and enhancing prosecutions - http://ec.europa.eu/justice/newsroom/ criminal/opinion/120307 en.htm, but also in greater detail European Commission [65; p.5].

${ }^{40}$ Because this question was not posed to OLAF staff who are, of course, specialists for crimes against the EU's financial interests.

${ }^{41}$ One cannot, of course, exclude that such opinions are also informed by the Commission's standpoint but these practitioners are also in a position to form their own opinion based upon what they feel about the field they work in. They were specifically asked for their own evaluation. There is also little indication that these assertions are incorrect with e.g. OLAF's latest annual report indicating that even after their investigations, criminal justice follow-up occurs only in a minority of cases and for limited conduct (OLAF [66; p. 21 and 35]). One can only speculate what this means for the dark number.
} 
Amongst the nationally-based interviewees $56 \%$ of prosecutors felt unable to provide an estimate as to the trend during the past years, whilst $26 \%$ said European crimes have been increasing and $18 \%$ thought they had not. Related specifically to the two distinct component strands of crime: $37 \%$ of the national EU financial interest experts believe these crimes to be on the increase, $29 \%$ say they are not with only $34 \%$ feeling unable to provide an estimate. Relating to trans-national crime, $81 \%$ of national experts declared themselves unable to provide an answer to this question whilst $11 \%$ stated such crimes to be on the increase and $8 \%$ that this is not the case.

Clearly this first section of study results is at best highly speculative and mostly inconclusive. It highlights only that the knowledge basis about the types of crimes for which the EU has introduced combatting mechanisms is unsatisfactory. ${ }^{42}$ No real conclusions can be drawn from such a diffuse picture except that further knowledge is needed about these criminal phenomena. The recently reformed Eurojust and Europol legal bases clearly demonstrate the EU legislature (at the time the member states) recognising this need. They further demonstrate the necessity of building such understanding at a supra-national level. National criminal justice authorities are now subject to further reporting requirements to supra-national agencies (see article 13 Eurojust Decision [20] and article 7 Europol Decision [21]). The latter should be placed in a position to understand the European picture as a consequence. In the medium term this should see EU agencies in a better position to inform about such criminal phenomena and criminal justice responses to them. Should this information shore up the speculation of EuroNEEDs interviewees that the majority of financial interest crimes are not being prosecuted, this will clearly favour the creation of an EPPO. If the indications relating to trans-national crime are proved correct and national authorities are able to deal successfully with the majority of cases, then this would speak against the need for an EPPO for these crime types.

Dedicated investigation The study hypothesis that European crimes pose problems to prosecutors due to their specific complexities, indicates a potential benefit of an EPPO as the specialised and dedicated investigations it could run. The challenge of European cases is, above all, that knowledge and evidence of the criminal activity resides beyond the borders of any one national prosecutors' jurisdiction. The central problem is for the prosecutor to access (and make available to the court before which s/he brings a case) any evidence required to prove the nature and extent of criminal activity. The European Union itself currently encompasses 29 jurisdictions, ${ }^{43}$ the border-check free Schengen area currently has 33 members and European cases may naturally further involve third states, meaning their coverage can be very significant indeed. Prosecutors investigating even aspects of such cases may face very significant geographic and jurisdictional challenges. The procurement of assistance from other jurisdictions is thus a decisive issue.

\footnotetext{
$\overline{42}$ See, for instance, the divergence of opinion between Petrus van Duyne and Ernesto Savona. Savona, favours a 'risk formulae': see Savona, E [67]. Duyne, on the other hand, considers this approach 'void' due to the lack of a valid definition in categorising such occurrences: see van Duyne P C.[68; p.63]. See also the question and answers session highlighting Van Duyne's views on this matter succinctly [68; p. $78 \mathrm{ff}]$.

${ }^{43}$ The United Kingdom, which counts as one member state, featuring three: England and Wales, Scotland and Northern Ireland. Croatia will become a full member of the EU on the 1st of July 2013.
} 


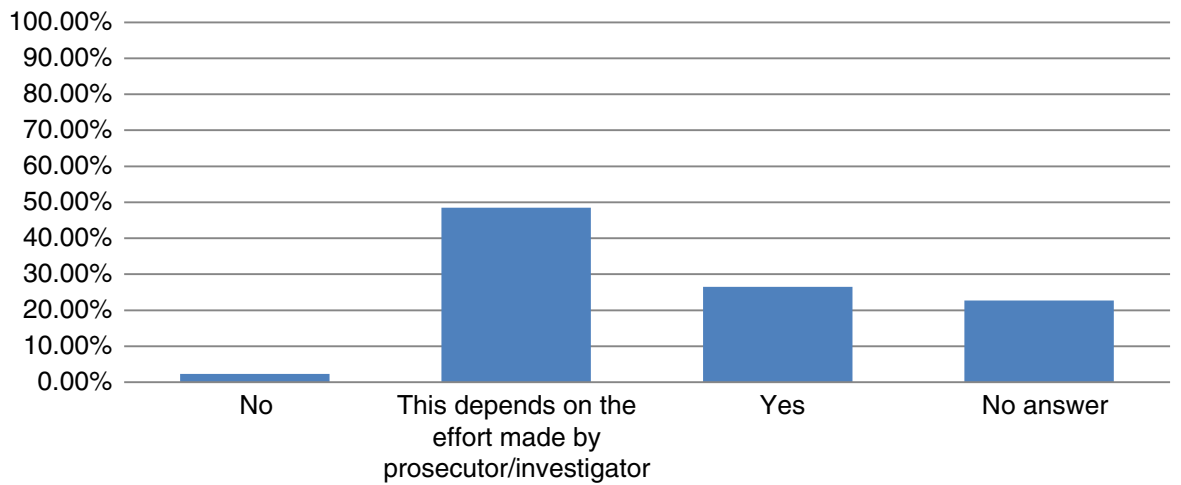

Fig. 1 National prosecutos: Do mechanisms in place to gather evidence abroad ensure success?

National prosecutors were therefore asked about mechanisms in place to gather evidence abroad. The vast majority reported mechanisms as being in place and generally adequate. ${ }^{44}$ When asked about the success of such measures, the responses presented in Figs 1, 2 and 3 resulted.

Only a small part of the study results concerning structural provision for European cases at national level is presented here. Clearly some provision is made to assist prosecutors in dealing with European cases and approximately one quarter of prosecutors feel this provision to be adequate. This result must, however, be seen in the study context: only prosecutors specialised in this kind of work were interviewed. It was not possible to expand the sample so widely that prosecutors who encounter such cases only once or twice within a career could be captured. Fundamentally, even amongst this expert group, the study demonstrates successful investigation hinging upon the ability and motivation of individual practitioners handling such cases. This will in turn depend to a great extent upon the training and circumstances these practitioners work within as determined by their sovereign nation states. Prosecutors across Europe are widely recognised as operating under resource pressures necessitating the prioritisation of those cases considered most important. ${ }^{45}$ The systems within which prosecutors handling European cases work do not necessarily prioritise European interests. Notwithstanding the excellent work done by many prosecutors, also recognised by the European institutions, this naturally leaves European interests in the hands of nationally-oriented structures operating under pressure. ${ }^{46}$

Clearly the creation of an EPPO should ensure a cadre of dedicated prosecutors across Europe motivated to prosecute the European cases for which they are given competence. Given the central importance of such motivation in gathering evidence across borders, this would be a key argument for an EPPO if such motivation is regarded as lacking.

\footnotetext{
${ }^{44}$ See Wade, M. [23;p.24 et seq.].

45 Jehle. J., Wade. M [69]Wade. M., Jehle. J. [9], Wade [70] and Luna/Wade [71] also recognised by the practitioners working in supra-nationalised institutions questioned in the course of the study see Wade [23; p. 43 et seq.].

46 Thus e.g. the call by Lothar Kuhl, head of the policy department of the Anti-Fraud Office of the European Commission (OLAF), in his plenary speech at the „Blueprint for the European Public Prosecutor's Office? EU model rules of criminal procedure conference, "13-15th June 2012, in Luxembourg, that a figure who "cares" about European interests is necessary.
} 


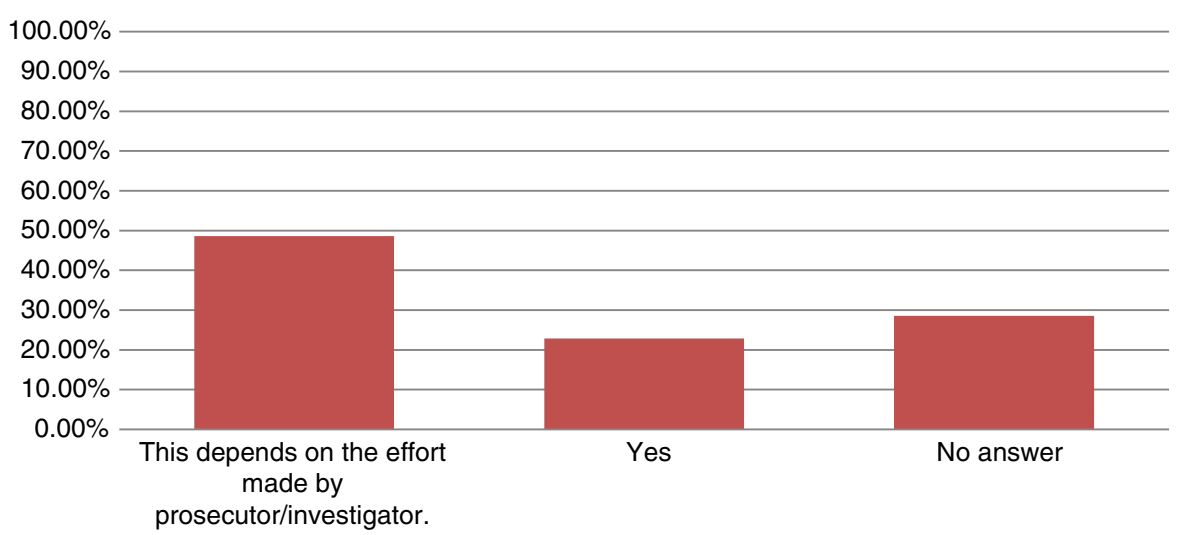

Fig. 2 National prosecutors - financial interests: Do mechanisms in place to gather evidence abroad ensure success?

When it comes to their specific experiences in providing assistance, a majority of prosecutors overall (just over half when analysed according to specialisation), reported no problems in obtaining and transferring evidence abroad. $23 \%, 14 \%$ (financial interests) and $34 \%$ (trans-national) respectively replied that they face complications. The difference between the low rate of problems relating to financial crime and the relatively high rate in trans-national cases is intriguing.

This difference is also apparent in interviewee responses to whether they have ever refused a request. The overall affirmative response rate is $36 \%$ with a large divergence between the two crime strands for which specialists were interviewed; $20 \%$ of financial interests experts have refused requests whilst this rate is $44 \%$ amongst trans-national crime specialist. It would thus certainly appear that the latter investigations witness practitioners facing greater problems. This may be due to a lesser degree of specialisation and expertise or indeed a lack of familiarity with their foreign counterparts. Supra-national interviewees indicated that the "financial interests world" is one in which investigators often know each other. Only 41 of 72 interviewees provided explanations why they refused requests from foreign colleagues (see Table 1) but of these, the vast majority reported refusals as occurring for

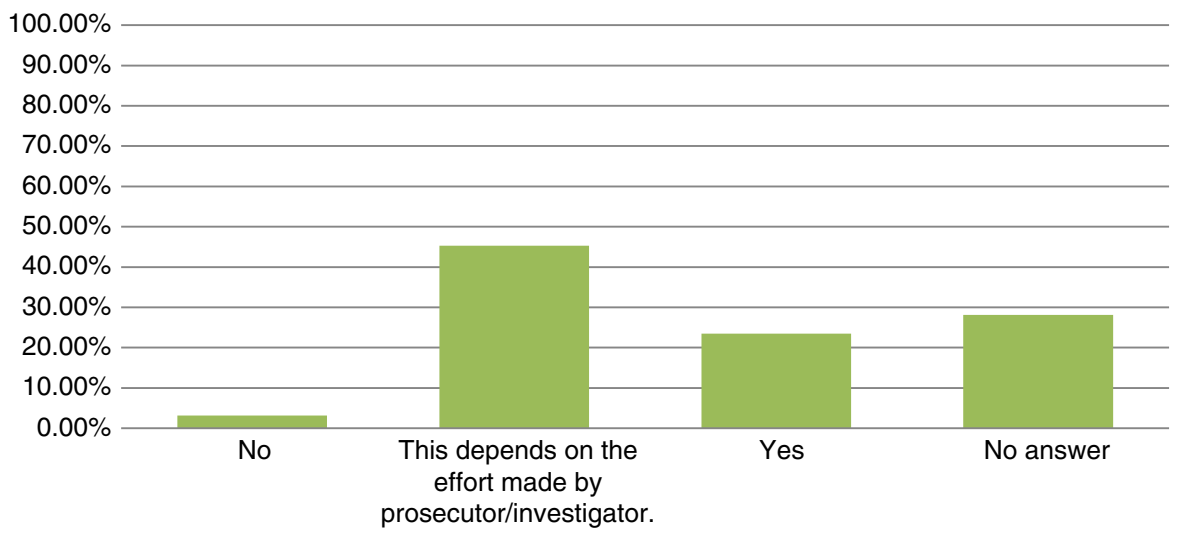

Fig. 3 National prosecutors - trans-national crime: Do mechanisms in place to gather evidence abroad ensure success? 
Table 1 National prosecutors: Most frequent reason for refusing a request

\begin{tabular}{llr}
\hline Fundamental legal reason & 19 & $14.39 \%$ \\
More practical legal differences & 10 & $7.58 \%$ \\
Too general/petty & 7 & $5.30 \%$ \\
Lack of resources/time & 1 & $0.76 \%$ \\
Not within the EU & 1 & $0.76 \%$ \\
Formal & 3 & $2.27 \%$ \\
No answer & 60 & $45.45 \%$
\end{tabular}

fundamental (constitutional) legal reasons or for more technical reasons (such as the conditions for a measure being subject to other preconditions in that member state). This accounted for $70.7 \%$ of refusals. In addition $17.1 \%$ stated requests were refused because these were too generally formulated or considered too petty.

The reasons given for refusing requests described by financial interests experts pointed, above all, to legal reasons with occasional remarks that requests are too loosely formulated. A number of those negating this question (i.e. saying they have not refused requests) point out that they have had to request additional information to avoid refusing a request (count: 4 of $15-43 \%$ of those who provided an answer). For trans-national experts the vast majority of reasons given also related to legal bars. In two cases (of 39 interviewees who provided the requested information as to their reasons), however, refusal ensued because national proceedings in the requested state were underway, a further two for capacity or policy reasons. A further two interviewees stated the requested act became impossible for practical reasons.

$38 \%$ overall, 31 and $39 \%$ respectively have experienced their own requests being refused. Again, not all interviewees provided explanations; in this context 72 (55\%) did: practical legal issues are the dominant problem (see Table 2). Fundamental legal issues, however, also play a role. Badly drafted requests or ones deemed not to be proportionate are mentioned at the same rate by those who have experienced their requests being rejected as those who have experience rejecting (compare Tables 1 and 2). Financial interests experts state, above all, legal reasons as having caused refusal but also a few cases in which their requests lacked the necessary precision. One interviewee described a request not being performed in time. A number of these specialist interviewees (7) state that their requests are not refused but point out that they are not fulfilled at all or alternatively not fulfilled in a timely manner, meaning that the end effect is the same. Trans-national expert interviewees similarly state formal, legal grounds as the

Table 2 National prosecutors: The most frequent reason own requests are refused

\begin{tabular}{llr}
\hline Fundamental legal reason & 9 & $6.82 \%$ \\
More practical legal differences & 19 & $14.39 \%$ \\
Too general/petty & 7 & $5.30 \%$ \\
Lack of resources/time & 4 & $3.03 \%$ \\
Not within the EU & 3 & $2.27 \%$ \\
No answer & 60 & $45.45 \%$
\end{tabular}


reason for the majority of refusals; 5 of these interviewees state that they do not receive formal refusals but experience the functional equivalent mentioned above. ${ }^{47}$

Relating to requesting transfers of evidence, the study is indicative of the kinds of problems discussed at the European level in association with the proposal for a European Evidence Warrant (EEW) and now the European Investigation Order (EIO) $[19,21]$. The expectation is naturally that the EIO will provide solutions to some of these. There are clearly legal bars to the successful procurement of evidence by prosecutors and, to a lesser extent, difficulties relating to how requests are formulated. The nitty-gritty of transferring evidence within the EU is - albeit exceptionally - still marked by significant problems with the law surrounding offences against the EU's financial interests appearing particularly problematic.

$60 \%$ of interviewees, however, state they have no problem requesting or receiving evidence. Expert interviewees have lower rates of refusing requests. Financial interest experts point to some very specific legal problems. ${ }^{48}$ These reports occur despite many interviewees' assertions that they try to check in advance whether their request is achievable. Such refusals are, however, an exceptional phenomenon. For such cases an EPPO operating under harmonised legal rules for evidence-gathering should overcome both the legal and practical problems currently associated with international evidence-gathering.

Evidence gathering is naturally not only a matter of accessing information an investigator already knows exists but also part of a dynamic investigative process. As such the EuroNEEDs study sought not only to measure whether prosecutors are able to access evidence in other jurisdictions but also to understand how they believe an investigation should ideally run.

Overall a clear majority of interviewees $(66 \%)$ state that they would prefer to become directly involved in evidence gathering abroad. 50 interviewees $(37.9 \%)$ say they would always like to be involved whilst $63(47.7 \%)$ only express this desire in relation to large and complex cases. Amongst financial interests specialists this rate extended to greater majority with $80 \%$ (93\% of those providing an answer) expressing this preference. In this category interviewees strongly expressed a need to accompany key stages of the investigation themselves in order to make quick, reactive decisions as to how to proceed. Only $6 \%$ negate a preference to be involved. This is a case of clear divergence from trans-national specialist interviewees of whom $28 \%$ see no need to be directly involved in evidence collection abroad, though a majority $59 \%$ (68 \% of those providing an answer) still expressed a preference to so be.

Several interviewees pointed out that they are currently able to participate in requested acts under legislation in force and do take up this option. ${ }^{49}$ There were no reports of requests of this nature being made and then refused. The extent of current active participation or presence is, however, not proportionate to the level of desire expressed for this. One might speculate that resources and working practice tend to militate against such participation being anything other than an exception. ${ }^{50}$

\footnotetext{
$\overline{47}$ Though two indicate that the refusals they have experienced relate exclusively to non-EU member states.

${ }^{48}$ A significant proportion of refusal reasons relate to finance-related legal problems e.g. bank secrecy 8 of 50 - so $16 \%$.

49 This is permitted under Article 3(1) of the European Convention on Mutual Legal Assistance, Strasbourg, 20.IV.1959; as well as Article 4 of the Council Act of 29 May 2000 [105].

${ }^{50} 4$ interviewees expressly state this to be the case though interviewees were not directly questioned on this point
} 
Prosecutors do not express any hesitation in relation to asking for evidence from foreign jurisdictions. ${ }^{51}$ The lack of priority or urgency with which their requests are treated (as indicated by their statements shown supra), however, provides a hypothetical reason why prosecutors might prefer to be involved directly in gathering evidence abroad. Investigative tactics and the ability to react as a case develops are, however, the most frequently explicitly mentioned reason for this by interviewees where they explained their answers.

Although national prosecutors have mechanisms at their disposal to gather evidence in European cases, the EuroNEEDs study demonstrates that this is still far from a simple matter and thus correctly one currently being tackled at the EU level. An EPPO with jurisdiction to gather evidence across the Union would naturally provide a solution to any such problems. It is not the only thinkable path to achieving efficient evidencegathering across the Union. Therefore whilst this is a benefit which might plausibly be associated with the establishment of an EPPO, it alone is unlikely to be accepted as grounds justifying the creation of such an office. The strong preference, particularly on the part of financial interest specialists, of prosecutors to run cases personally is another matter. This would seem to indicate very clearly that investigations are best run by the intended prosecutor who is thus placed to develop a case dynamically. There can be no clearer endorsement of a prosecutorial figure acting supra-nationally.

A major potential benefit of an EPPO would be to release the European dimension of cases from their dependency upon the national level. ${ }^{52}$ For information purposes they would presumably still rely upon the member states in parallel to article 13 Eurojust Decision [20] and article 7 of the Europol Decision [12] however the obligations of member state authorities to report would certainly have to be strengthened. ${ }^{53}$ Furthermore, unlike the current situation in which Europol must ask a member state to initiate investigations ${ }^{54}$ or a Eurojust prosecutor might ask a national colleague to launch an investigation or prosecution ${ }^{55}$ (as indeed do OLAF), an EPP will be able to investigate and, where appropriate, prosecute in his or her own right. In doing so the EPP would be acting as an agent of the European Union, seeking to combat phenomena threatening European interests and values. Often this may be subtle, but this would certainly be a different perspective from that represented even by member state prosecutors working collectively for example in J.I.T.s. The major point is of course that those heading the structures in which prosecutors work at present have other priorities than the European dimension of such cases. ${ }^{56}$ Even agencies working at the European level are bound by the will and "national agenda"

\footnotetext{
${ }^{51}$ Of the general responses, $87 \%$ stated themselves as happy to so. See Wade [23; p.37]. For financial interests specialists this number is $89 \%$, for trans-national specialist it is $86 \%$ ).

${ }^{52}$ Currently viewed by some as a weakness of Eurojust - see Suominen, A. [46; p.226].

${ }^{53}$ See article rule 4 of the model procedural rules developed by the Luxembourg project ran by Ligetti [72]; the availability of information to a supra-national agency or institution was recognised as key in reforming Eurojust's legal basis which was intended to provide for a more pro-active work style-see European Commission [73; p.3].

${ }_{55}^{54}$ In accordance to article 7 of the Europol Decision [21].

${ }^{55}$ Some, though by no means all, of the national members of Eurojust retain their powers as national prosecutors to investigate and prosecute. This naturally depends entirely upon the member state concerned and is reflective of the national member's status within his or her own domestic jurisdiction not within a supra-national order. See articles 6 and 9 (3) Council Decision setting up Eurojust [74]; as well as the amending Council Decision $[20,103]$ and Wade, M. [75; II.C.2.].

${ }^{56}$ On the separation of powers and interests to prosecute fraud against the financial interests of the EU see Neuhann, F.[76; p.535].
} 
of the member states. ${ }^{57}$ An EPPO would change this and issues of delay should also largely fall away in investigations by a suitably structured EPPO.

Comprehensive prosecution The central advantage of a supra-national office responsible for investigation and prosecution lies in the potential to handle cases in their full dimension; as European matters overcoming the national boundaries which mark our current criminal justice systems. The very idea of creating an EPPO must centrally aim to ensure the internal borders of the EU pose no impediment to prosecuting crime, to provide for a full investigation leading to a comprehensive prosecution and then a sentence reflective of the criminal activity involved in its entirety.

Dealing with the European dimension The next step in attempting to gauge in how far national systems currently charged with doing so are able to deal comprehensively with European cases was simply to ask interviewees whether they felt hampered by the European dimension of cases when investigating them; in other words whether this dimension made their work significantly more difficult when compared to national cases meaning that such cases may fail. Naturally this pre-supposes that investigators will always be aware of the European dimension of their cases (which may well not always be the case - see supra-nationalised practitioners opinion on this infra). Furthermore a case being hampered does not mean it will ultimately not be successfully investigated and prosecuted to some extent. Nevertheless, if the very fact that a case has a European dimension, more than 10 years after the Tampere Council, is attested as being a problem in itself and indeed as hampering (not merely complicating) a case, this provides grounds to believe that national criminal justice practitioners may need further assistance in dealing with such cases or that changes to the way in which such cases are dealt with may be justified.

The majority of national prosecutors, and of the respective specialised prosecutors interviewed, answered in the affirmative that the European dimension of such cases hampered them in handling European cases. Of those answering no when asked this question, many stated the word hamper as being too strong preferring to describe the European dimension as a complication. In other words, the European dimension of cases makes them harder for prosecutors to work. For a majority of $55 \%$, for financial interest specialists $60 \%$ and for trans-national crime specialists $58 \%$ this difficulty is at a level they perceive as hampering their work often to the point of European cases failing as such. Interviewees identified several aspects of such cases as problematic. Above all it is the practicalities of such cases which make the European dimension a hampering factor though legal and procedural problems are apparently not to be underestimated (see Figs. 4, 5 and 6). The study results interestingly show a higher reporting of legal problems relating to the countering of offences against the EU's financial interests - perhaps indicating that this requires particular attention. This certainly lends legitimacy to the European Commission's recent initiative to harmonise this aspect of substantive criminal law [22].

National prosecutorial interviewees were further questioned to what extent the European dimension could be a bar to a case being comprehensively dealt

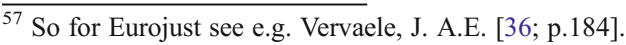




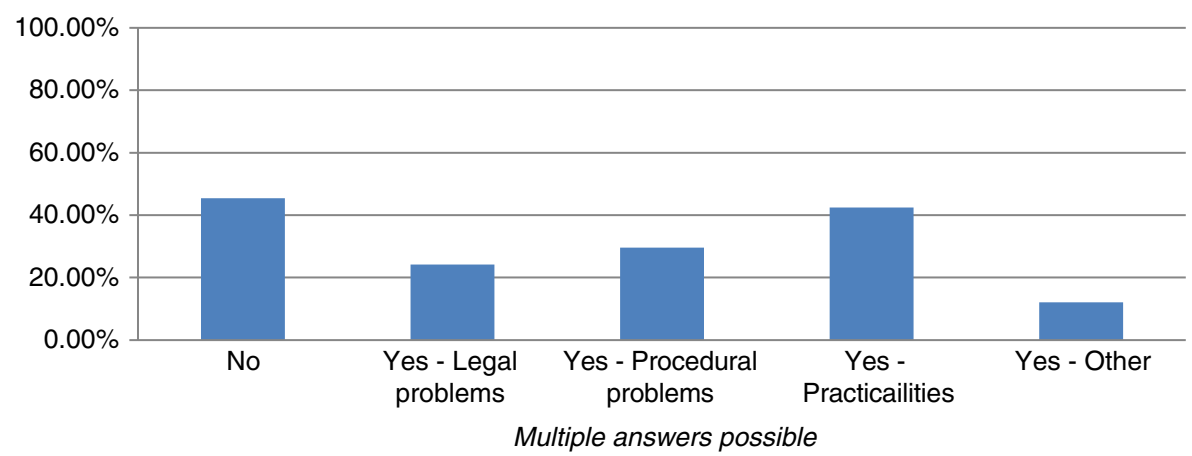

Fig. 4 National prosecutors: Are such investigations hampered by the European dimension?

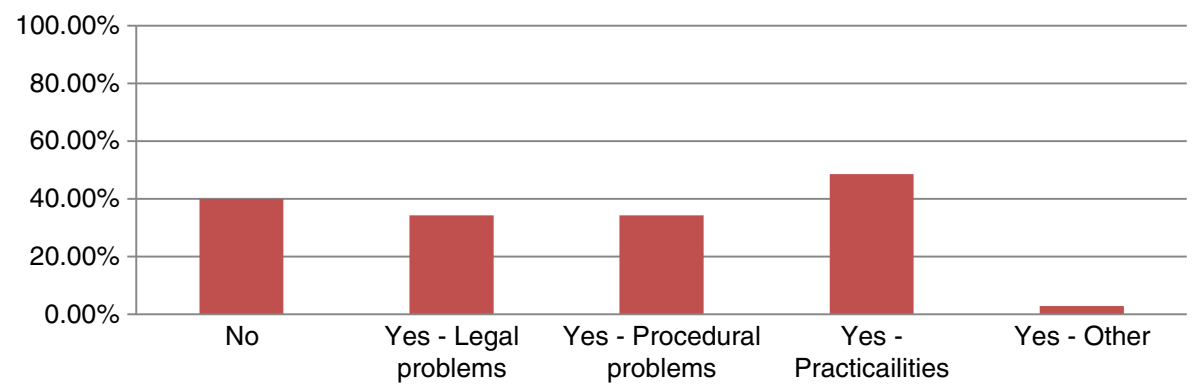

Multiple answers possible

Fig. 5 National prosecutors - financial interests: Whether investigations are hampered by the European dimension?

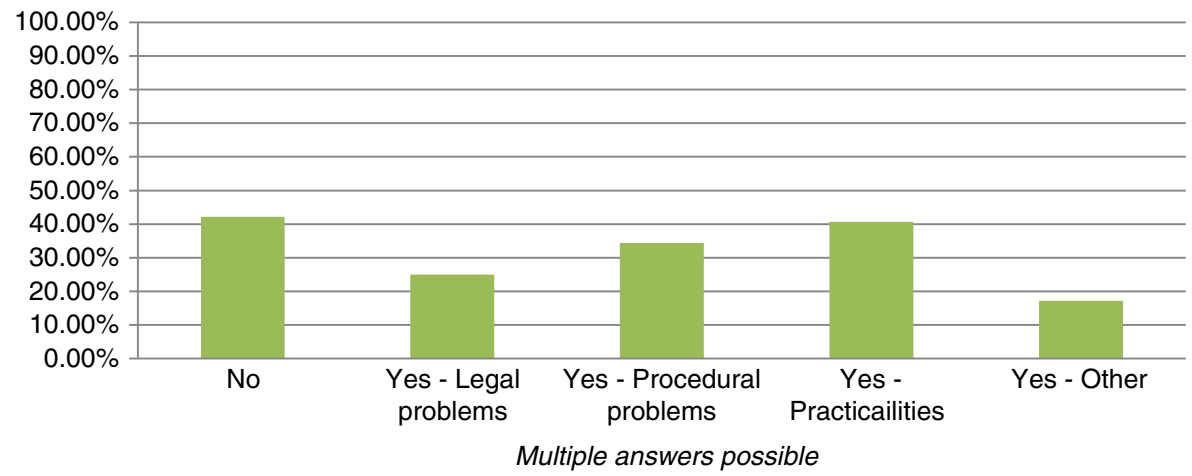

Fig. 6 National prosecutors - trans-national crime: Whether investigations are hampered by the European dimension? 


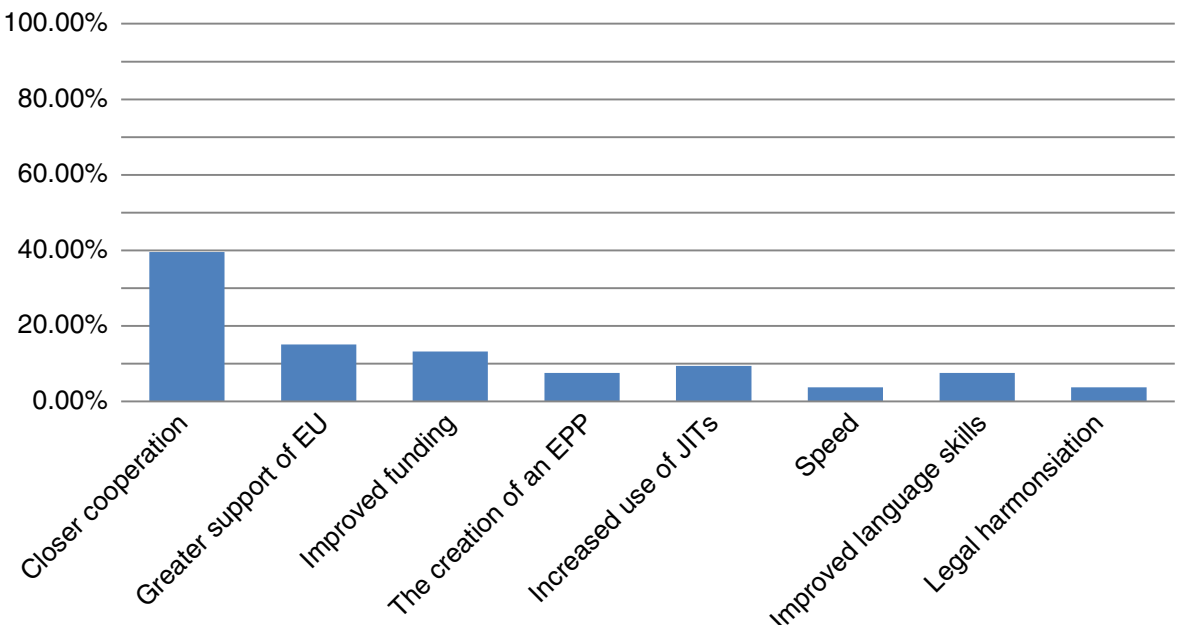

Fig. 7 National prosecutors unable to pursue European dimensions: Suggestions how this could be overcome

with because, even though they recognised this dimension, they felt unable to pursue it.

Overall $48 \%$ stated that the European dimension is a bar to a case or forms an aspect of cases which cannot be dealt with. In other words almost half of the national prosecutors questioned assert that, at least sometimes, the European dimension of cases must be left aside and an investigation focused merely upon what has taken place upon national territory. A significant number of European cases can thus clearly not be prosecuted as such. In cases of this kind, the full dimension of crime may well not become known and cannot be prosecuted. ${ }^{58}$ The evaluation of specialists answers display $52 \%$ of trans-national cases as (at least sometimes) being restricted in their investigative scope whilst a slightly larger majority (of $54 \%$ ) of financial interests specialists stated this to be the case.

This point is underlined by the results of the supra-national EuroNEEDs interviews. A clear majority - $63 \%$ overall, $57 \%$ relating to EU financial interest related offences - of these interviewees express the opinion that the member states' authorities fail to adequately recognise the true dimensions of such crimes. This confirms that from the very outset such crimes stand no chance of being handled as the European cases they are. Furthermore $60 \%$ (64\% of EU financial interest specialists) identify a tendency of member states' investigative authorities to reduce investigations to aspects of national relevance. The supra-national interviewees thus confirm the results gained from national prosecutors, underlining more strongly that European cases are either not recognised as such or, where they are, the European dimension will frequently be neglected as investigators are forced or choose to streamline their investigation. Figures 7 and 8 illustrate how prosecutors believe the reduction of cases to aspects of national interest may be avoided.

\footnotetext{
${ }^{58}$ One might even expect that the number of prosecutors answering this question in the affirmative is under-representative. Several of the systems included in the study feature prosecutors bound by the principle of legality and by an ex officio duty to investigate crimes fully and might thus be reluctant to admit to not doing so.
} 


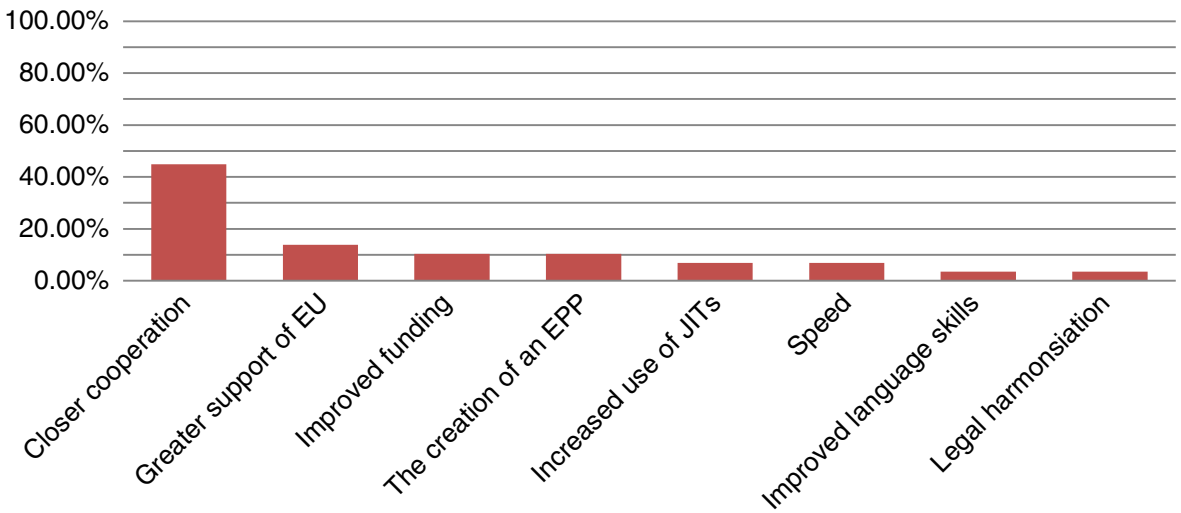

Fig. 8 National financial interests prosecutors unable to pursue European dimensions: Suggestions how this could be overcome

The EuroNEEDs study results therefore identify a number of points which must be regarded as problematic from the European perspective. A majority of prosecutors testify to being hampered by the European dimension with financial interest experts indicating that legal complexities pose particular problems for them. Around half the prosecutors interviewed furthermore reported limiting their case work to aspects of national relevance meaning the European nature of cases goes neglected. Finally the study makes clear that the pursuit of European aspects is reliant upon the efforts of individual prosecutors. This research thus indicates that the current criminal justice response to European cases is not comprehensive and unlikely to be consistent (dependent as it is upon national prosecutors' circumstances). Clearly in this situation comprehensive prosecution cannot ensue. This is a clear argument supporting the need for structural change such as an EPPO. A figure of this kind operating under harmonised definitions of financial offences should, by its very nature (working Europe-wide) be able to guarantee full investigations not hindered by national borders in what is investigated thereby providing the necessary informational basis for comprehensive prosecution. ${ }^{59}$

This picture is confirmed by supra-national interviewees. Almost $60 \%$ of supranational interviewees state that such cases are investigated inadequately in the member states. Over $60 \%$ of EU financial interest experts state this to be the case. Supra-national interviewees were often careful to stress this is not a matter of will or competence on the part of their member state based colleagues ( 9 supra-national interviewees $-30 \%$ - expressly state that failures are due to other factors) but they were firm in their evaluation of the result. A vast majority ( $83 \%$ overall and $86 \%$ for EU financial interest specialists) stated that insufficient resources are available for the investigation of such cases though other factors ${ }^{60}$ are also stated to hinder investigations. This was clearly seen to lead to inadequate prosecutions with $60 \%$ of supra-national interviewees, $71 \%$ of EU financial interest specialists among them

\footnotetext{
59 This last point may be indicative of legal reform being necessary. Given, however, that the financial regulations relating to EU funds form part of a complex and autonomous legal order, one might just as well argue that specialist structures dealing with them would also solve this problem.

${ }^{60}$ Such as differences in laws, a need to take new paths, a lack of training, an inability to see the full perspective of cases and unwillingness to take cases on and deal with them in their entirety.
} 
confirming this. A number of respondents explained explicitly that no adequate prosecution can follow inadequate investigation; others chose to limit their affirmation of adequacy in consideration of prosecutions possible given the material provided by the investigations conducted. Clear indication is provided that the current prosecution of European cases, particularly financial interests cases is inadequate viewed from the European perspective provided by supra-national interviewees.

Practitioners working in supra-national institutions also clearly identify the European dimension as hampering investigations (60\% overall and $71 \%$ of financial interests experts) thus confirming the answers given by their national counterparts (see Figs. 9 and 10). In fact, they express more strongly that this is the case. Possibly this is due to their recognition of more cases as European than their colleagues working in national settings. Most frequently supra-national interviewees identify the practicalities of such cases as causing cases to be hampered. Differences in law, bad past experiences and even the perception of complexity and indeed unwillingness of practitioners to act because they are set in their ways, are, however, also identified as causal problems as illustrated in Figs. 9 and 10.

It is interesting to note that inadequacies are highlighted as particularly marked in the investigation stage. The tendency to reduce prosecutions only to matters of national relevance is reported as markedly lower overall (40\% compared to $60 \%$ ) than in relation to investigations. This is, however, not true in relation to the EU's financial interest with $57 \%$ of specialist practitioners working in supra national institutions declaring that such reduction happens. It is important in interpreting this data to bear in mind that a majority of $67 \%$ and $57 \%$ of EU financial interest specialists negate expressly prosecutors as taking on such cases primarily when asked to do so by supra-nationalised institutions. This demonstrates simultaneously that enforcement of the law is dependent upon member state authorities but also that these often take such cases on upon their own initiative. Furthermore there is some agreement that member state authorities treat European offences with the same priority as national ones; in other words the reasons (when this is the case) these cases are not treated entirely satisfactorily, are the same as why complex national cases are not dealt with adequately[23; p.49 et seq.].

Interestingly agreement that there is no specific discrimination against European cases is particularly strong amongst EU financial interest specialist, supra-national interviewees at $64 \%$. Financial crimes are complex, time-consuming and resourceintensive full stop; their investigation and prosecution generally marked by compromise and inadequacy it would seem. When prosecutions of trans-national crimes are

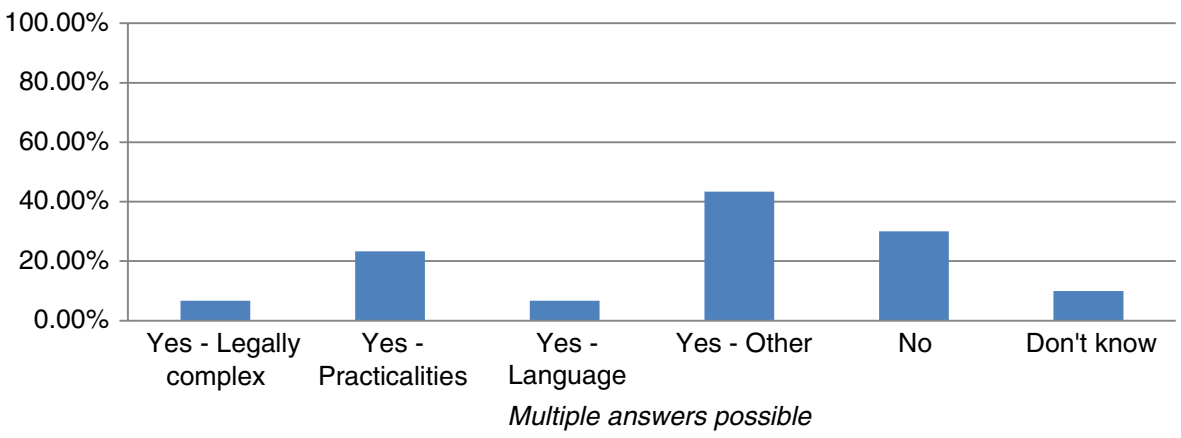

Fig. 9 Supra-national interviewees: Member state investigations hampered by the European dimension? 


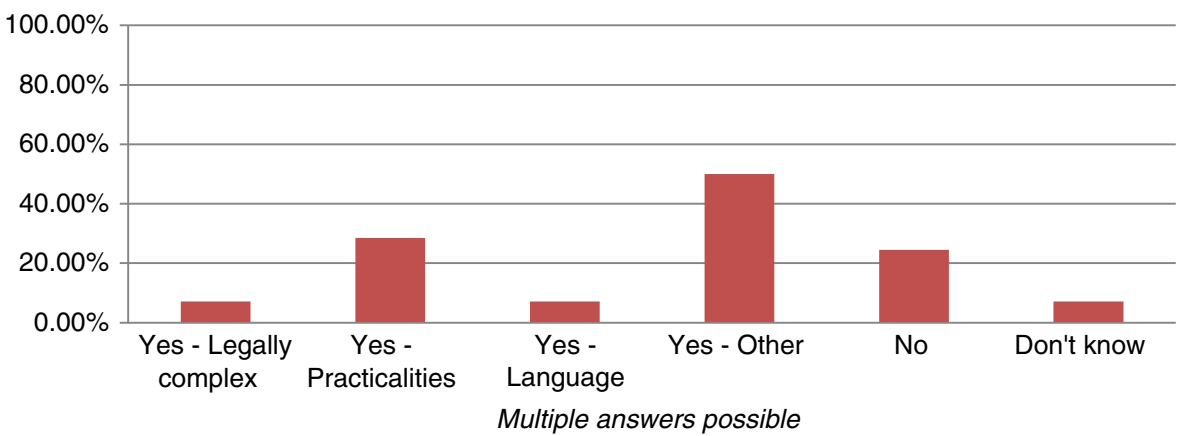

Fig. 10 Supra-national interviewees financial crimes: Member state investigations hampered by the European dimension?

included in the calculation, supra-national interviewees are less confident they are treated equally with only $50 \%$ agreeing that they are.

However, the overall figures display $27 \%$ of supra-national interviewees contradicting the majority of national interviewees' belief that European cases are treated with the same priority and $23 \%$ responding they have insufficient knowledge or providing no answer. EU financial interest specialists have more clearly formed opinions with only $14 \%$ not expressing an opinion and $21 \%$ disagreeing (vehemently) with a notion that member states protect the EU's financial interests as well as their own [23;52 et seq.].

Summary One can therefore note a majority of national prosecutors and a clearer majority of prosecutors working in supra-national settings attesting to European cases being hampered as such. Almost half of national prosecutors and a majority of supranational interviewees identify investigations being reduced in scope. Offences against the financial interests are somewhat more likely to be recognised as European cases but investigations into them are particularly liable to being reduced. They are then disproportionately subject to reduction at the prosecution stage.

The reasons for this state of affairs lie mostly with the nature of trans-national cases though occasionally supra-national interviewees identify the law and the attitudes of national prosecutors as causal. The study, however, also highlights trans-national cases as particularly in danger of being treated with lesser priority meaning that for these crimes, the nature of criminal justice systems sometimes speaks against their successful prosecution.

Despite their mostly positive note - that the member states do not discriminate against enforcing the law in European cases, interviewees working in supra-national settings (who are, after all, former national investigators or prosecutors) are fairly unified in their assessment of the current enforcement situation as inadequate. $80 \%$ of supra-national interviewees overall regard the situation as less than adequate or requiring improvement whilst not one EU financial interest specialists regards the current scenario as adequate or better [23;42 et seq. and p.50]. As to the details of the current set-up, a clear majority ${ }^{61}$ regard the resources devoted to these cases as

\footnotetext{
${ }^{61} 60 \%$ overall $-81 \%$ of those providing answers; again Europol based practitioners remained reticent in providing an opinion - and $71 \%$ of EU financial interest specialists.
} 
inadequate. It is interesting to note that none of the interviewees in supra-national settings attested to member state authorities decreasing in their willingness to investigate or prosecute cases [23, pp. 47 et seq.]. The problem is not fundamentally identified as one of will it would seem; the study gives little indication of European cases being actively discriminated against. They suffer from lack of recognition and, amongst other things, from resource shortages.

National prosecutor interviewees agree with the supra-national interviewees' impression that the European dimension suffers at the hands of member states' national criminal justice systems. Within these, priority is naturally assigned to cases in the order perceived by the member states. If member state authorities do not fully recognise European cases - as is indicated in the analysis above, this cannot but lead to inadequate investigations and prosecutions. Furthermore referral to resource shortages is frequent and this inadequate status quo is a natural consequence. The member states have no reason to denote the resources needed to European cases as opposed to others they view as more important.

Implications There is nothing surprising or indeed underhand about this finding per se but the EuroNEEDS study may be taken to provide evidence to those who assert that the member states do not protect European interests at the same level as their own. This cannot but lead to calls for a more active, independent system or independently resourced activity to ensure the European dimension of cases is adequately attended to. An EPPO would from its very conception be better placed to recognise cases as European. Any design for an EPPO not ensuring it can overcome the practical problems currently associated with trans-national investigations and is endowed with the legal expertise to handle financial interest cases, would defeat its very purpose. A European public prosecutor investigating across the territory of the Union would have no reason to reduce the scope of investigations and thus be well placed to ensure European crimes are comprehensively understood and prosecuted as such.

If one interprets these results in the best possible light (and in the diplomatic spirit with which these interviews were doubtlessly often approached), the EuroNEEDs results can be seen as mostly exonerating the member states from any discrimination against European cases depicting these often as the victim of structural deficiencies (via the enforcement systems when viewed against the criminal groups and phenomena concerned) and resource shortages. This lends credence to calls for new structures and lends the argument that a system to enforce the law regulating the protection of the EU's financial interests could pay for itself (and should thus not be held hostage by the member states' resource shortages)[24; p.7] significant weight.

An EPPO operating on the territory of the EU as a whole would clearly be premised on the idea that $\mathrm{s} / \mathrm{he}$ will prosecute comprehensively. ${ }^{62}$ It should be noted that there are two interests in comprehensive prosecution. Not only does it ensure that all victims and interests affected are considered by a court or courts across the Union and thus the criminal activity in all its facets responded to by criminal justice systems. Ideally this will also ensure that sentencing reflects the extent of criminal activity. ${ }^{63}$ This will

\footnotetext{
${ }^{62}$ On OLAF's current inability to provide for this see Xanthaki, H. [47; p.138]. For a more detailed overview see Xanthaki, H.[77].

${ }^{63}$ For reflection upon appropriate sentencing see: A Ashworth and J Roberts [78; p.867].
} 
certainly be lost when cases are not fully prosecuted but restricted only to the interests of one member state or evidence available in it. Proportionate sentencing may well, however, also be lost when prosecution takes place over many member states if such efforts are not co-ordinated and sentencing bodies made aware of convictions in other member states. Clearly an EPPO amalgamating all activity into one case or controlling prosecutions in several jurisdictions, would be well placed to counter such problems.

Prosecutors traditionally work in systems anchored in territorial nation states answerable to that state's parliament. The adoption of policies which take account of activities threatening another sovereign might appear hostile if not done in cooperation with and accompanied by the permission of that other nation state. If just sentencing is an issue for more complex criminal activities transcending borders, then those defending a traditional idea of state sovereignty ${ }^{64}$ might well call for better information for sentencing judges and multi-lateral agreement concerning appropriate sentencing as a promising alternative.

The majority of prosecutors interviewed in the course of the study were, however, individuals who feel they are tasked with combatting crimes and criminals. This more functional approach witnesses the latter unfettered by borders and prosecutorial wishes to respond quid pro quo. As the European Union consolidates as a governance level, prosecutors recognise a logic in assigning some responsibility to this supranational level. If comprehensive prosecution is strived for, and it is difficult to imagine anyone not arguing that this should be the case for serious, organised and cross-border crime, a well-resourced and suitably structured EPPO is undeniably well suited to deliver this.

Efficiency/improved quality The EuroNEEDS study not only captures the facts of European investigations and prosecutions but also explored practitioners' opinions of the developing situation. EuroNEEDS study interviewees were thus provided with an opportunity to discuss potential reform paths. Although the questionnaire did not explicitly refer to an EPPO, reference to a centralised prosecution body was almost exclusively (by all but three of 162 prosecutorial interviewees) interpreted by interviewees to mean precisely that (as opposed to any national or even regional alternative). The interviews for this study took place in the time period immediately before and after the Treaty of Lisbon came into force and in which the Spanish EU Presidency and the new European Commission lent this topic a high profile.

Interestingly the majority of prosecutors working in national criminal justice systems state there is no need for further mechanisms and agencies in order to deal with European cases $(62 \%, 57 \%$ among financial interests specialists and $59 \%$ of trans-national experts [23;p. 39]) but were surprisingly divided as to the potential benefit of a European Public Prosecutor.

$51 \%$ of national interviewees overall stated that an EPPO would improve the investigation and prosecution of European cases (see Fig. 11). $42 \%$ declared that a(n improved) support service would be preferable in a separate question (see Fig. 12). Perhaps not entirely surprisingly the affirming majority is slightly higher for

${ }^{64}$ The key limiting factor in European criminal justice integration/co-operation matters - see e.g. Vervaele, J. A.E. [79; p.181]. See also p. 183 for the limiting effect of such concerns on the development of Eurojust. 


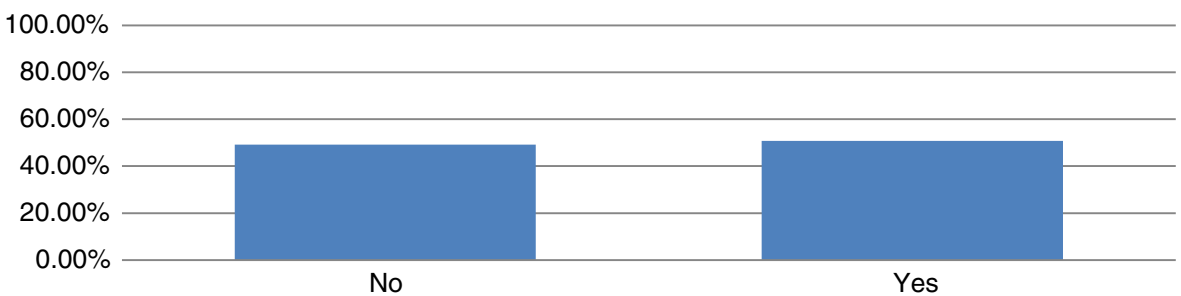

Fig. 11 National prosecutors: Whether the situation would be improved if a centralised, specialised investigation/prosecution unit be assigned exclusive jurisdiction for such cases?

nationally-based EU financial interests specialists (54\%) and the situation is reversed for trans-national specialist national interviewees (amongst whom $47 \%$ believe an EPPO would improve the situation). Interestingly amongst EU financial interests specialists, $49 \%$ of national interviewees state that a support service would be preferable and adequate whilst amongst trans-national specialists this is $47 \%{ }^{65}$ National interviewees recognise the potential benefits of an EPPO though many of them would prefer a support service, usually developed further than what is currently in place.

As is consistent with other responses, supra-national interviewees were more clearly supportive of an EPPO potentially improving the investigation and prosecution of European cases with $57 \%$ stating this. In relation to EU budget cases, i.e. the introduction of an EPPO solely to deal with financial interest offences, this was a more convincing $67 \%$. Supra-national interviewees were, however, in part hesitant to answer this question emphasising the political nature of such a decision. Even amongst those affirming the improvement such a move would bring, a few interviewees were careful to emphasise that the final decision will not be made on this kind of factual basis and that there are good reasons for this. A larger number (11 so $36.7 \%$ ) were, however, adamant as to the need for an EPPO. A majority (57 \%) also explicitly rejected the idea of even an improved support service as preferable to an EPPO.

Amongst supra-national interviewees specialised in dealing with EU financial interests related cases, this standpoint was vastly clearer. The greater majority of $79 \%$ state the need for an EPPO, whilst $86 \%$ do so specifically for EU budget cases. $86 \%$ also reject an even improved support service as preferable. Particularly in relation to EU financial interests, a certain degree of impatience was detectable amongst this group of interviewees with several of them explaining that attempts have been made over decades to deal with European cases in a co-operative setting and that this is simply insufficient.

\footnotetext{
${ }_{65}$ The Luxemburg report expresses clear puzzlement on practitioners' behalf as to the suggestion of a European public prosecutor noting that there are feelings it is based upon a political lobbying for a European jurisdiction and a political rather than judicial need. Whilst an exploration of this topic is not excluded, many practical concerns are expressed above all a lack of clarity in competence definition and the fact that a European public prosecutor would need to plead before national courts but be far removed from national practice thus lacking acceptance and legitimacy-Braum [80; p. 16-7]. The opinions of Luxembourg prosecutors are integrated into the overall figures wherever possible although they had to be gathered in a different manner to other countries. For an explanation of the particular methodology used there see Wade, [23;p.8]
} 
$100.00 \%$

$80.00 \%$

$60.00 \%$

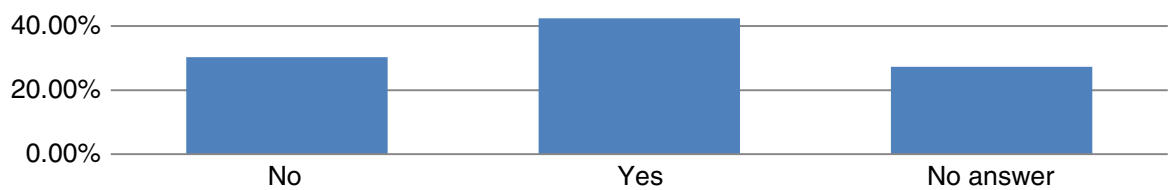

Fig. 12 National prosecutors: Whether a support service would be preferable/adequate?

A majority of national prosecutors and of those working in supra-national settings thus recognise an EPPO as providing for greater efficiency and a higher quality of investigations and prosecutions. This recognition is heightened amongst financial interests specialists and particularly strong amongst those at the supra-national level, lending weight particularly to the arguments for an EPPO in relation to financial interest offences. These findings are explored in greater detail below.

The need for greater efficiency and improved quality Determining the need for any particular kind of further development of the European criminal justice system on an empirical basis is a complex matter. The questions underlying this study are highly political, the interviewees involved well aware of this, as well being of differing opinions, experiences, age and nationality, etc. There is much room for argument, for interpretation, for questioning whether certain answers are not coloured by a political or even emotional leaning, let alone an opinion expected by their professional hierarchy. For this reason interviewees were led through a series of questions which in some cases approached a singular problem or complex from a number of different perspectives. In the cross-referencing analysis which follows the consistency of interviewee answers is tested, helping to draw a clearer picture of the problems faced by criminal justice practitioners and the solutions they view as potentially promising.

The first major point to highlight is that $31.8 \%$ (42 of 132 national prosecutorial interviewees -22 financial interests specialists) indicate that they have no problems in the day to day handling of European cases. In other words a significant majority of $68.2 \%$ of the nationally-based prosecutors interviewed within the course of the study see themselves facing specific problems relating to these kinds of cases.

Deeper analysis of these interview results show that of those 42 who claim not to experience any problems themselves, 32 (12 of whom are financial interests specialists), still call for further development at the EU level. 18 interviewees (including 7 financial interest experts) express support for an EPPO, 3 (1) further say such an office would be an improvement though they would prefer a support service. The remaining 11 (4 financial interest experts) see potential improvement in individual EU measures such as those suggested by the study questionnaire (which were centralisation of information and or evidence and a central service organisation to organise coercive measures to provide for evidence requests, etc. [23; p.132 et seq.]).

The apparent contradictory call for further, and indeed strong institutionalisation (although these prosecutors claim not to face any of the problems identified by the study) 
is explained by statements that these interviewees do not face the problems themselves, but know they hinder other colleagues; that they can only not report such problems because of the significant efforts they make to overcome them or that the current enforcement system is fragmented and much too slow. In other words the bar the study questionnaire set ("hampering") in discussing problems with European cases was a high one. Therefore, although these interviewees negated the question as asked by the study, the majority of them regarded European cases as marked by particular challenges and these challenges as justifying further institutional development at the European level.

Seen from the opposite perspective, only $7.6 \%$ of interviewees (10) report having no problems dealing with European cases or seeing no benefit from further enhancing the institutional provision for combatting such crimes at the European level. This leaves $92.4 \%$ who declare themselves to be facing hampering problems or desiring supra-national development.

Of those who report facing problems, however, 8 advocate no further development. Four of these identify their problems as relating to practicalities, resources and differing attitudes - matters which they do not believe can be addressed by structural reform. Four state that the system is essentially working as it should be. One prosecutor states that reducing the scope of cases is part of his job and should not be viewed as problematic, another that any decisions as to development are for the Attorney-General to make. A further response was that cases are not started "if they are doomed" but recognises no need to change this situation.

In conclusion: $13.6 \%$ of the nationally-based prosecutor sample are against further developments at the European level either because they feel they face no problem when dealing with such cases or because they view the system they work in, whatever faults it may have, as working satisfactorily.

If we turn to the 114 nationally based interviewees who have suggestions as to how to solve their problems or see need or potential for improvement by change at the European level, 47 (35.6\% of the complete sample) of 132 unequivocally believe an EPPO would improve the situation. A further 18 (13.6\% of the sample overall) believe an EPPO would help improve the situation but would prefer a support service to be used. Of these 65 (49.2\% of the entire sample who believe an EPPO would represent an improvement), only four (3\% of the sample overall, $6.2 \%$ of those who believe an EPPO would represent an improvement) state that an EPPO's powers should be restricted to protecting the EU's financial interests. 36 (of the 114 who desire further development $-27.3 \%$ of the sample overall) state that a support service is what is needed (and an EPPO is out of the question). Only 4 of these expressly state that the status quo is adequate whilst more explicitly add that Eurojust must be given further powers for the current set-up to suffice. There is clearly disagreement as to how criminal justice should develop at the European level: centring around a supranational prosecutor or in co-operative guise.

In relation to the area for which an EPPO is likely to be proposed in 2013: the protection of the financial interests of the EU, the EuroNEEDS study identified 35 of the nationally-based prosecutorial interviewees as pure financial interest experts (a further 30 also deal with such cases but their opinions could not be assigned exclusively to experience from such cases so they were only evaluated as part of the overall results unless this is explicitly stated to be otherwise. They are considered 
in the following calculation). 13 of these $35 \mathrm{EU}$ financial interest offences experts declare themselves supportive of an EPPO (this is $37.1 \%$ of financial interest experts, which represents $9.8 \%$ of the sample overall), a further $7(20 \%$ and $5.3 \%$ respectively) believe an EPP would improve the situation but would prefer a European support service to be installed. Of the 30 who also deal with financial interest crimes, 11 (36.7\% of this category of prosecutors, $8.3 \%$ of the sample overall) are supportive of an EPP whilst $3(10 \%$ and $2.3 \%$ of the sample overall) believe an EPP would improve the situation but prefer a European support service. In other words, of those who have experience dealing with financial interest crimes $52.3 \%$ (25.8\% of the sample overall) believe an EPP would improve the situation though $15.4 \%$ (7.6 \% of the sample overall) of those calculated into this percentage state that they would prefer an improved support service. Support for an EPPO amongst those dealing with financial interests crimes (here defined more broadly) is thus somewhat higher than the entire sample average of $49.2 \%$ whilst preference for a support service is significantly lower than the $42.2 \%$ calculated overall. This latter figure in the overall sample (the $42.2 \%$ ) naturally includes the interviewees who do not view an EPP as a potential improvement, i.e. those viewing a support service as the only viable option.

The picture of opinion relating to an EPPO is thus divided and complex. Discussions with practitioners working European cases at the national level leave no doubt, however, that action is needed to improve the efficiency and quality of criminal justice responses to European crime.

\section{Initial conclusions}

The EuroNEEDs study provides indications of specific problems associated with European cases which an EPPO should be better placed to deal with than national prosecutors. It can therefore be used to address the calls for proof associated with criticism of the EPPO idea. ${ }^{66}$ Expert practitioners speak less of matters such as improved co-ordination of cooperation mechanisms or a denationalised approach to prosecution. The benefits they associate with an EPPO relate more to concrete factors such as recognition of the full dimensions of a case and the benefits of one person bearing responsibility for an investigation with that person overseeing and actively leading the collection of all relevant evidence as the case develops.

The EuroNEEDs study thus indicates that the creation of an EPPO is not merely to facilitate greater efficiency in what is currently done. This argument has traditionally been advanced in its favour ${ }^{67}$ and should, of course, be a factor ${ }^{68}$ but the study's data draw attention to a more fundamental shift to be achieved

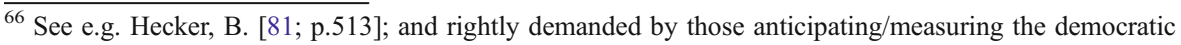
and constitutional costs of such an institution - see Braum, S. [80; p.511]

${ }^{67}$ E.g. by the Commission's Green Book on criminal law protection of the financial interests of the Community and the establishment of a European Prosecutor [8; p.76]and strongly criticised as a primary goal which leaves many substantive arguments in its wake - see e.g. Braum, S. [80]

${ }^{68}$ Identifying the laborious nature of MLA as a key factor. See Radtke, H. [82; p.9]
} 
by such an office: the combatting of crime in the European, not national, public interest.

\section{Reservations and pitfalls}

The very idea of a European perspective or public interest in the prosecution of crime, goes to the heart of one major policy battlefield; the question whether the member states want to acknowledge the existence of any such thing via a criminal justice office. The decision to create an EPPO or not thus goes to deeper governance issues. The central question is whether the European dimension of cases is important enough to recognise a European pubic interest in full investigation leading to comprehensive prosecution.

Fundamentally this is, of course, a political decision. In the coming year politicians will have to decide how far any European public interest goes. ${ }^{69}$ Is there any interest in combating crime greater than the sum of member state interest? Does this require the creation of a supra-national criminal justice agency as the European Commission looks set to argue? Some member states will doubtlessly insist that the principle of subsidiarity ${ }^{70}$ requires the Union to allow the member states criminal justice systems to protect the former's interests. In relation to the financial interests of the Union, the Commission is making the argument that decades of inadequate protection demonstrate this is not enough. ${ }^{71}$ The practitioners interviewed during the course of the EuroNEEDS study indicate this to be true. The study also demonstrates some criminal phenomena as requiring combatting in a way which exceeds the interests of the member states, even when working collectively as currently provided for, because they require a different level of recognition and specifically dedicated investigation. The current ability of criminal justice systems to respond to some crime is portrayed as less than satisfactory. Whilst some problems may be particularly acute for financial interests offences, trans-national crimes also leave national prosecutors facing significant challenges.

The current situation sees national prosecutors positioned as relatively distanced service-providers to their colleagues abroad in European cases. This appears problematic given the strong desire to be directly involved in evidence gathering voiced by national prosecutors (38\% stating cases would run better if this were so, $80 \%$ amongst financial interest specialists). There would thus certainly appear to be a need felt by practitioners to see - at least a significant proportion of their cases - run during investigations by the person who identifies with the case as a whole and can decide how to develop it as new facets emerge across Europe. Prosecutors are, however, the agents of criminal policy and not those who set it. What is then the nature of the European public interest expressed by the criminal justice related policies of particularly the last decade?

\footnotetext{
${ }^{69}$ This remains very much as summarised by Costa, J. [83; p.149].

${ }^{70}$ As anchored particularly in article 5 but also in substance in article 4 of the post Lisbon TEU.

${ }^{71}$ See e.g. Commission of the European Union [65; p.5]The OLAF Report 2011 [66; p.35]
} 


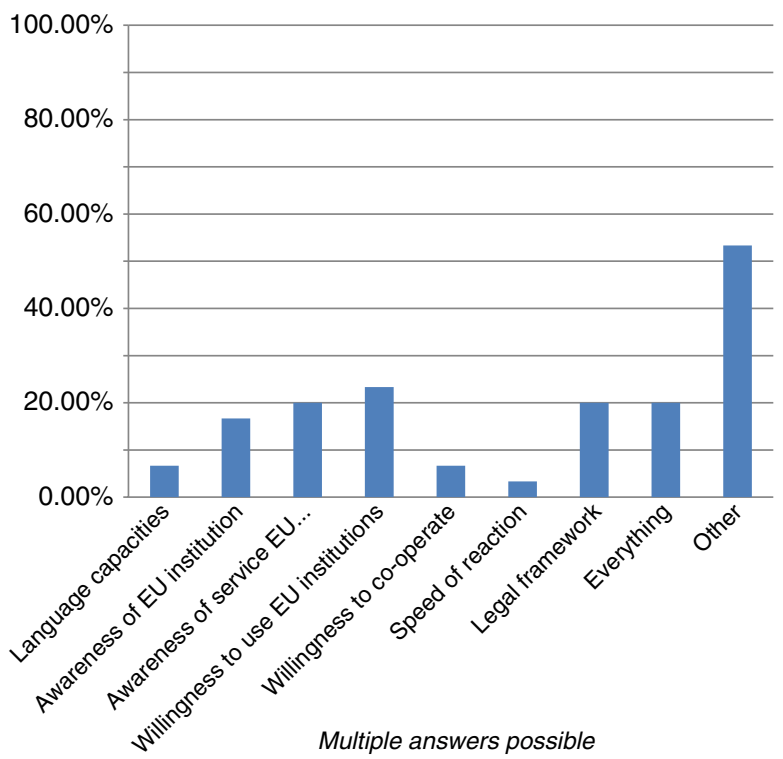

Fig. 13 Supra-national interviewees: What could be improved?

Does the European Arrest Warrant merely represent a mutated form of mutual legal assistance (firmly in nation state hands) or is it the expression of a need for a new criminal justice order? In creating a European Arrest Warrant did the member states not express a European public interest in ensuring freedom of movement rights are not exploited? Or should this be qualified merely as a collective expression of national public interest? Did the Schengen accord in fact signal the dawn of a new approach to territory and law enforcement within it? Is there any interest in ensuring that European cases are recognised as such and investigated and prosecuted accordingly?

Considering what is at stake, there can be little doubt that arguments against an EPPO will be forceful. It cannot be ignored that the EuroNEEDs study also supplies data which provide the basis for arguments against its introduction at this time.

A premature development Even a preliminary analysis of the EuroNEEDS results also demonstrates that practitioners feel there is room for improvement within the current scenario (see Figs. 13 and 14).

One might conclude from these indications that further institutional development at this point would be premature ${ }^{72}$ because until the mechanisms in place are being used properly and fully, one cannot truly determine the necessity of any further reform. The principle of subsidiarity can be argued to require the Union to allow

$\overline{72}$ As suggested e.g. by Hecker [81; p. 514]. 


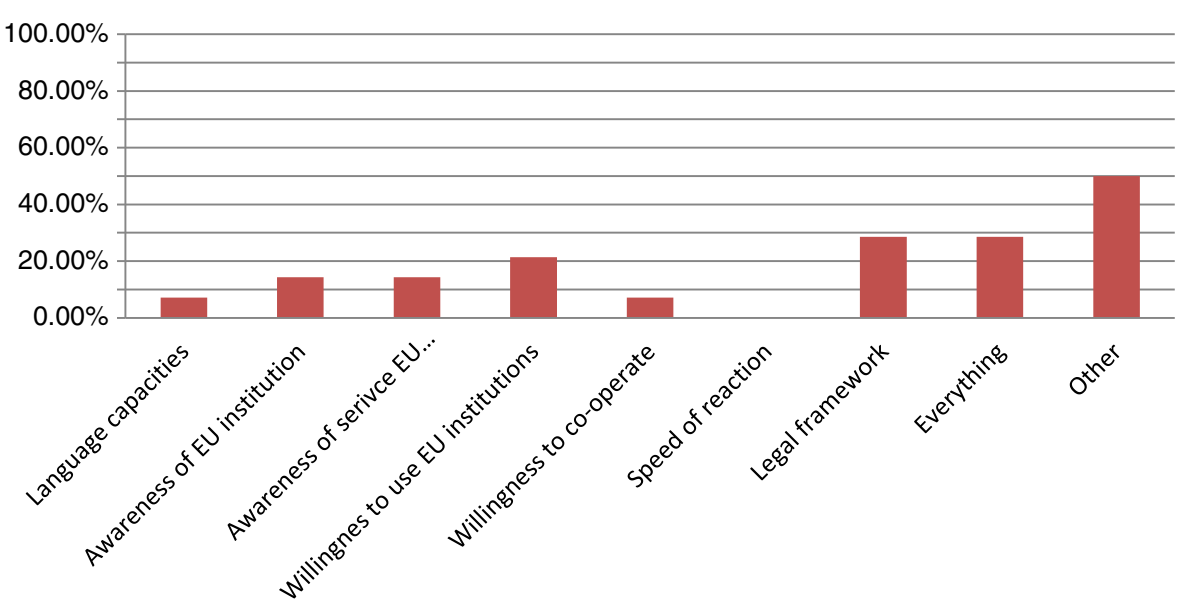

Multiple answers possible

Fig. 14 Supra-national interviewees - financial interests: What could be improved?

the member states to try all other mechanisms until these are demonstrated to be inadequate. If practitioners report that there is significant room for improvement in the current system, any inadequacies identified can be taken to indicate a need for training and information but not institutional reform. The EuroNEEDs statistics do, however, also pertain to aspects which may be difficult to improve upon. When supra-national interviewees explain that the attitude national prosecutors have to supra-national institutions requires attention (their willingness to use EU institutions is illustrated as having the highest potential for improvement both overall and by financial interests experts), this can just as easily be regarded as indicative of a need for fundamental change in the prosecution set up as a need to influence and train prosecutors.

Whilst the Commission may be entirely justified in asserting that the creation of an EPPO is in line with the principle of subsidiarity - the holy cow of Union law and strongly reasserted by the member states in the Lisbon Treaty $^{73}$ - pointing to the member states' failure over decades to provide equivalent, proportionate and effective sanctions ${ }^{74}$ in response to offences against its budget, the study results do lend themselves for counter-argument. The EuroNEEDS results clearly point also to the possibility of redoubling efforts to ensure national authorities use the support institutions currently available to them at the supra-national level. Furthermore Europol and Eurojust operate on the basis of fairly recently reformed legal bases which are once again subject to on-going reform negotiations. ${ }^{75}$ Member states which prefer the investigation and prosecution of European cases to take place via such mechanisms cannot but argue that such reforms should be allowed time to bed down and their effectiveness then be assessed before further reform is

\footnotetext{
$\overline{73}$ See e.g. articles 4 and 5 TEU.

${ }^{74}$ Case 68/88, Greek Maize, [1989] ECR 2965-In this classic case the ECJ asserted in the 1980s that the member states are obliged to protect Union (then Community) interests as their own.

75 This point was made e.g. by the German legislature see [42; p.2].
} 
Table 3 Supra-national interviewees: How could matters be improved?

\begin{tabular}{lll}
\hline Legislative reform & 7 & $\begin{array}{l}23.33 \% \\
\text { harmonisation ( theory) } 5 \\
\text { national legislation 2 }\end{array}$ \\
Investigate at EU level & & $13.33 \%$ \\
Bring cases at EU level & 4 & $13.33 \%$ \\
Better use of existing tools & 4 & $13.33 \%$ \\
Simplification & 4 & $10.00 \%$ \\
Training & 3 & $10.00 \%$ \\
Closer co-operation with member states & 3 & $10.00 \%$ \\
Policy setting at EU-level & 3 & $3.33 \%$ \\
No answer & 1 & $13.33 \%$ \\
\hline
\end{tabular}

undertaken. ${ }^{76}$ This argument carries particular weight if the proposed next step is the creation of a truly supra-national criminal justice institution, which is perceived as encroaching so strongly on the sovereignty of member states.

As supportive as they were of an EPPO, the opinions of interviewees in supranational institutions could be taken in part to underline this:

As demonstrated in Tables 3 and 4 significant proportions of the practitioners in supra-national institutions interviewed think existing tools can be used better and that simplification, training and closer member state cooperation could improve the situation. This is part tallies with the opinions of national prosecutors illustrated in Figs. 7 and 8 supra. Legal reform is also regarded as bearing potential by a significant number of interviewees.

Interestingly the potential for improvement by such means is, however, not recognised by financial interests experts. The only improvement suggestions garnering a clearer level of support (just under $30 \%$ - see Table 4 ) relate to the supra-nationalisation of investigative and prosecutorial powers. Thus although the study points to remarkable similarity between financial interest and trans-national crimes in terms of the challenges faced by prosecutors dealing with them, the practitioners working at supra-national level interviewed felt more can be done in relation to trans-national crime within the bounds of mechanisms currently available than is the case for financial interest crimes.

Arguments for delaying any decision regarding an EPPO except for financial interests offences are strengthened by a majority (57\%) of supra-national interviewees stating that national authorities already have adequate tools to deal with European cases. Interviewees often bemoaned the main problem as being that they do not use them. Only amongst the financial interest expert interviewees was a larger number of practitioners (precisely $50 \%$ ) to be found asserting that the national authorities lack something as opposed to a minority of these experts who view the tools available as adequate. The will of member state authorities (and how open to influence this is) will

\footnotetext{
${ }^{76}$ See e.g. Brady, H. [84] and Donoghue [64; p.11]. Also comments on the introduction of OLAF, Europol and Eurojust in 2003 but with equal application, given reforms and new mechanisms - Saetzger, A. [85; p.138].
} 
Table 4 Supra-national interviewees financial crimes: How could matters be improved?

\begin{tabular}{lll}
\hline Legislative reform & 3 & $21.43 \%$ \\
Investigate at EU level & & $28.6 \%$ \\
Bring cases at EU level & 4 & $7.14 \%$ \\
Better use of existing tools & 4 & $7.14 \%$ \\
Simplification & 1 & $7.14 \%$ \\
Training & 1 & $7.14 \%$ \\
Closer co-operation with member states & 1 & $7.14 \%$ \\
Policy setting at EU-level & 1 & $7.14 \%$ \\
No answer & 1 & $7.14 \%$ \\
\hline
\end{tabular}

potentially form a great part of any coming debate. Supra-national interviewees in the EuroNEEDs study indicate the crux as fundamentally national versus EU interests and that the workings of national systems cannot be easily geared towards the latter. Thus they testify to the necessity of an EPPO. The counter-argument is obvious and not new with the central question thus becoming how long the member states can require the EU to wait patiently for improvement.

Such a result cannot but indicate the potential for controversy. Those who are less favourably disposed to an EPPO might well argue that encouragement and empowerment of practitioners to use the tools at their disposal to deal with European cases is what is required. ${ }^{77}$ Those supportive of an EPPO may well point to efforts having been made in this direction and perhaps to the fact that the attitudes of nationally-based criminal justice practitioners are marked by the priority afforded these cases by their systems. The supra-national interviewees in the study indicate the inadequacy of the resources at the disposal of such practitioners. In relation to the financial interests of the European Union, these interviewees were certainly making a case that what is missing is an EPPO; a criminal justice figure with the necessary overview of European criminal phenomena as well as the knowledge and resources to combat this successfully. These is a case which will nevertheless have to be made politically.

Perhaps not surprisingly the study's nationally-based interviewees are markedly more conservative across the board than their colleagues working in supra-national settings. Overall and among EU financial interests specialists $26 \%$ of national interviewees declared further mechanisms or agencies to be necessary, amongst trans-national specialist interviewees this was $25 \%$. A clear majority (of $62 \%$, $57 \%$ and $59 \%$ respectively) explicitly negated any such need.

It should be noted, however, that 28 (or $21 \%$ of the sample overall and $34.1 \%$ of those answering this question with no), went on to qualify their statement. Having declared that no further mechanism is necessary, they nevertheless explained that the situation could be improved by an EPPO, the

\footnotetext{
${ }^{77}$ In the past not only the interface between national authorities and supra-national institutions was criticised but also the obstacles to effective co-operation between those institutions themselves, see e.g. White, S. [86; p.82-83]. Study interviewees working in OLAF, Europol and Eurojust often spoke also of the efforts being made to optimise these working relationships.
} 
centralisation of information and evidence and/or a central EU service to apply to for all evidence from coercive measures in all 27 member states. In other words a slim majority of $54 \%$ underlined that the situation would be improved by further institutional development (see supra under "The need for greater efficiency and improved quality"). ${ }^{78}$

An unworkable model? Whilst the EuroNEEDS study clearly points to issues which might be resolved by a European Public Prosecutor and indeed demonstrates a very significant level of support for such an institution amongst the professionals currently tasked with this kind of work, the opposition it demonstrates cannot be ignored. Even if the political case for a European Public Prosecutor is made and it is structured suitably (a matter which also represents a formidable challenge; this is an office to potentially cover a territory of over 4 million square kilometres and a population of 495 million people ${ }^{79}$ ), an EPPO cannot work in isolation. $49 \%$ of national prosecutors rejected the idea that the investigation and prosecution of European crimes would be improved by an EPPO and even amongst financial crime experts this was $46 \% .27 \%$ of the sample as a whole is vehemently opposed the idea of an EPPO. As illustrated above, of those who viewed an EPPO as potentially improving the situation, $15 \%$ prefer a support service, in part citing reasons relating to acceptance by colleagues who oppose a supranational institution. Even an EPPO introduced to protect the financial interest of the EU faces significant hostility from the very start.

There are other indicators of difficulty, however. Supra-national interviewees were, for example, also asked whether they estimate member state authorities as preferring certain types of mechanisms to facilitate their cases and as to what kinds of assistance national criminal justice practitioners turn to them for. They responded that member state authorities have clear preferences. $23 \%{ }^{80}$ state the latter as tending to prefer direct contact amongst the member state authorities or mechanisms which leave them in charge rather than transferring power to a supra-national level. The same proportion point to a preference of paths familiar to their national colleagues and which they have experienced as successful in the past; efficiency, freedom from bureaucracy and not challenging the national prosecutors' authority are also criteria mentioned (see Tables 5 and 6). Financial interest experts are significantly more interested in gaining direct access to their colleagues (perhaps reinforcing the overwhelming desire to control evidence collection demonstrated by the equivalent national interviewees). Such preferences are not easy bedfellows for a supranational authority.

The requests directed to supra-national interviewees are most frequently for legal expertise, practical intervention, advice, co-ordinated action and the acceleration of mutual legal assistance requests (see Fig. 15). Interestingly there was no general agreement amongst supra-national interviewees as to what is working particularly well in co-operation with the member states just as there is great variety in their opinions as to what could be improved and how. Above all they appear to view

\footnotetext{
${ }^{78}$ Wade [23; p.111-112].

$79 \mathrm{http} / /$ europa.eu/about-eu/facts-figures/living/index_en.htm

80 incorporating two further comments.
} 
Table 5 Supra-national interviewees - MS authorities prefer certain types of co-operative mechanisms

\begin{tabular}{llr}
\hline Answer & Count & Percentage \\
\hline Direct contact & 5 & $16.67 \%$ \\
Co-ordinated action & 0 & $0.00 \%$ \\
Other & 17 & $56.67 \%$ \\
Of which: familiar (used before) & 6 & $20 \%$ \\
Of which: familiar (in sense of language/equal) & 4 & $13.38 \%$ \\
Of which: successful before & 2 & $6.67 \%$ \\
Of which: unbureaucratic & 2 & $6.67 \%$ \\
Of which: not challenging user authority & 2 & $6.67 \%$ \\
No (N) & 4 & $13.33 \%$ \\
Don't know (D) & 4 & $13.33 \%$ \\
\hline
\end{tabular}

themselves as working well in connecting professionals and facilitating co-operation. None of these findings contradict the need for an EPPO, they are, however, indicative of difficulties such an office may face in its daily work if it wrestles with prosecutors for control of cases.

The study demonstrates practitioners working at national and supra-national levels increasingly interacting with one another [23; p.47 et seq. and p.89]. The results, however, also indicate national criminal justice professionals as preferring and using mechanisms which leave them in charge of the process in particular in relation to trans-national crimes. Clearly this must raise concerns as to how well an EPPO will be accepted and whether the national prosecutors s/he works with are likely to be co-operative. No matter how well resourced the EPPO is, it will still have to work in co-operation with and to a large degree with

Table 6 Supra-national interviewees, financial crimes: MS authorities prefer certain types of co-operative mechanisms

\begin{tabular}{llr}
\hline Answer & Count & Percentage \\
\hline Direct contact & 5 & $35.71 \%$ \\
Co-ordinated action & 0 & $0.00 \%$ \\
Other & 8 & $57.14 \%$ \\
Of which: familiar (used before) & 3 & $21.43 \%$ \\
Of which: familiar (in sense of language/equal) & 3 & $21.43 \%$ \\
Of which: successful before & 0 & $7.14 \%$ \\
Of which: unbureaucratic & 1 & $7.14 \%$ \\
Of which: not challenging user authority & 1 & $7.14 \%$ \\
No (N) & 1 & $0.00 \%$ \\
Don't know (D) & 0 & \\
\hline
\end{tabular}




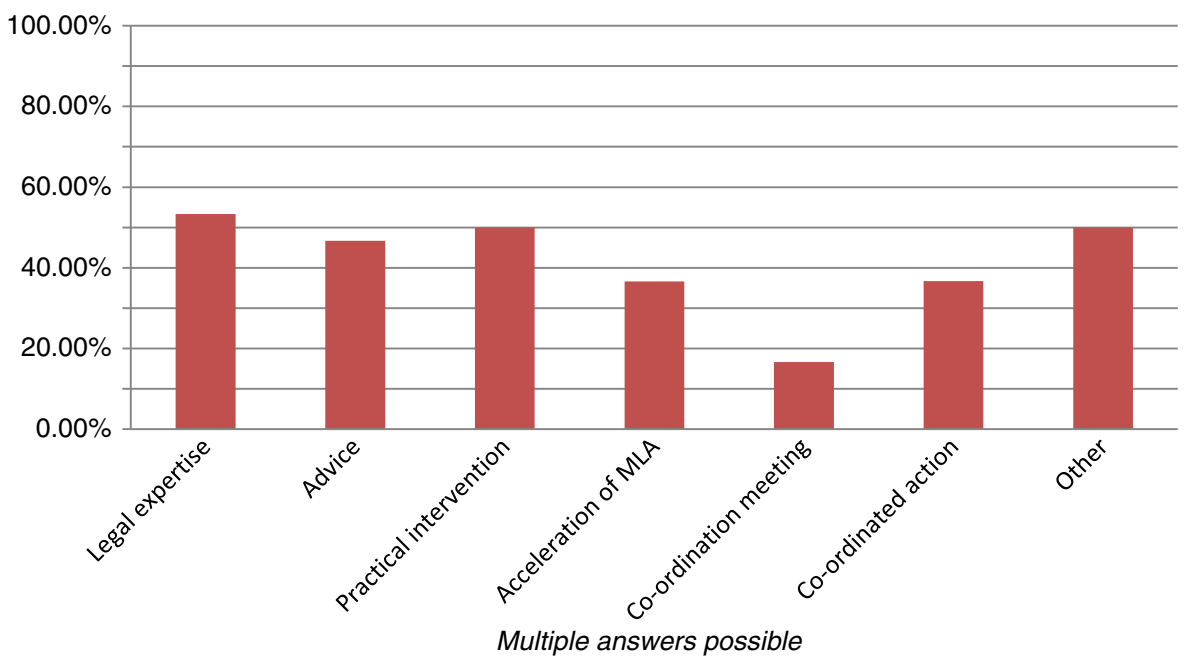

Fig. 15 Supra-national interviewees: MS authorities usually contact with request for

dependency upon national criminal justice systems. ${ }^{81}$ The fact remains nevertheless that an EPP may well not be able take over the majority of cases and must thus develop a suitable structure. One potential model perhaps is the Italian anti-mafia prosecution structure which sees a very powerful central body always with the potential to take over any case usually remaining in the background so that, in fact, successful policy still depends upon regional and local prosecutors [25]. Clearly such issues would have to form the second tier of considerations for an EPPO; if and when the considerable first hurdle has been passed. A lack of acceptance or a sense of encroachment on the side of national prosecutors would seriously undermine any potential efficacy of an EPPO. The status quo is quite plainly that the prosecution of European cases is largely dependent upon the will, skill and action of national criminal justice practitioners and that, to a certain extent, also appears to be how they like it.

If steps are taken to develop an EPPO, they must be taken in recognition that this is a controversial institution in criminal justice contexts alone. In other words, even amongst the specialist practitioners who recognise the problems they and their colleagues face in dealing with European crimes, there is significant opposition to the idea of an EPPO. Broader political contexts are likely to be more and not less concerned with e.g. the issues of sovereignty which sometimes underlie this opposition. ${ }^{82}$ This study is of course concerned with the practitioner view and opposition in this particular context may stem from context-specific factors such as a fear of

\footnotetext{
${ }^{81}$ At best structures similar to the cartel enforcement bodies might be achieved meaning the Union body determines the spread of caseload. As the Commission argues that effective and dissuasive sanctioning can only be achieved via even-handed and comprehensive prosecution [65; p.5], it is clear that the EPPO must operate within a web of national enforcement agencies not only feeding it cases but also prosecuting cases it cannot deal with itself.

${ }^{82}$ See e.g. Mitsilegas who describes the E.P.P. as "perhaps the most contested issue in the development of EU criminal law in recent years" - Mitsilegas, V. [49; p.229]. Interestingly in its famous Lisbon Treaty judgment the German Constitutional Court has laid less emphasis on institutional development than on substantive law - see Suhr, O. [87; p.706 et seq.].
} 
additional work or ones authority being challenged. This view should, however, be as strongly formed by factual arguments as it can be. Amongst the practitioners who deal with European cases, an EPPO has strong support but it is also the subject of clear rejection from significant sections of this community. The reasons for opposition are difficult to fathom; doubtlessly some of it is politically based but it is clear also that some practitioners feel strongly that they and the national systems can and should cope. Any structures establishing an EPPO; the how of an EPP installation ${ }^{83}$ and indeed the who are likely to be crucial issues [see 107]. If they are not handled well, an EPPO can be unworkable for a multitude of reasons which cannot be explored within the remit of this article. Significant challenges are, however, seemingly inevitably to be faced in establishing the necessary co-operation with national prosecutors. Precisely this cooperation is of course vital for a functioning EPPO.

\section{Reconciling the EuroNEEDS results}

It is not entirely simple to draw policy conclusions from this analysis. Taken together with the results discussed above, the cautious study finding that an EPP bears potential to improve the currently unsatisfactory solution but will face an "uphill battle" establishing itself amongst national prosecutors is confirmed. One thing is, however, indisputable: practitioners working on European cases in the member states require further resources and support mechanisms to improve their handling of these cases. The consolidation of institutions and mechanisms introduced so far as foreseen by the Stockholm programme [15; p.20], would clearly assist practitioners in identifying which channels and mechanisms to use. Increased use of the facilities already at their disposal will benefit European cases. Further mechanisms are, however, necessary to overcome the main hurdles faced by prosecutors handling them. Whether such further institutions should be supra-national is often presented as a matter of faith.

Those who deny the need for any further development at the European level captured in this study, for the most part do not assert that European cases are fully investigated and prosecuted. They observe criminal justice systems to be working correctly. European cases falling foul of practical hindrances or prosecuted only in so far as they relate to the interest of the sovereign state in which the prosecution takes place is the logical consequence of the residence of power with nation states. ${ }^{84}$ One must surely legitimately ask whether this is correct in the Europe in which national criminal justice systems bow to the assumed mutual trust between the member states which underlies the "cornerstone" of police and judicial co-operation; the Europe in which free movement is a fundamental right? Is this truly a Europe of the nation state? From another perspective one must equally question whether this is an acceptable approach in combatting such crimes. Our focus is serious, cross-border, organised crime.

\footnotetext{
$\overline{83}$ On potential for this see Nieto, A. et al [88]. For initial ideas see Espina Ramos, J.A./I. Vicente Carbajosa [16]; Satzger, A. [89; p.159 et seq.].

${ }^{84}$ Overall 29 national prosecutorial interviewees state that reducing the scope of cases is part of their normal work. Of these two state it is a rare and a third that this is for pragmatic, tactical reasons e.g. to allow the disruption of criminal activity. A further 3 interviewees appear to agree with this stance as part for their work whilst a further two, and another partially, see problems described as hampering European cases in a similar light.
} 
Crimes which nation states have willingly made the subject of trans-national law and (particularly post-Lisbon) the supra-national law of the EU. Is not the very heart of justice and home affairs policy of the EU that national borders should pose no impediment to prosecution? Allowing them to is certainly not conducive to the EU as a single legal area ${ }^{85}$ let alone a European public interest.

Many of those answering these questions within the course of the EuroNEEDS study view matters from a national perspective marked by particular experience. In the last decades, the common experience of most European prosecutors (prosecutors in sovereign states across Europe) has been that of system change allowing the non-prosecution of petty crimes in order to reserve sufficient resources for serious cases [9]. Some EU member states have, however, rejected such a notion as unsuitable and indeed immoral. ${ }^{86}$ The move to reduce the number of cases criminal justice systems respond fully to is unquestionably a fundamental policy decision; a decision not to invest as many resources as it takes to deal with all crimes - a question of social balance, in other words. The decisions of member states to be selective in their prosecutions, does not necessarily colour, let alone pre-form, that of the European Union. As has been stated in other contexts, the EU represents a unique governance level for which much can certainly be learned from its member states but, ultimately nothing can be seen as a predicating example. ${ }^{87}$ Alone the diversity of the member states on such issues calls the EU to review the situation in its own right.

The EU and any emerging European criminal justice system is not at a stage at which it must begin defining principles to reduce the reach of its criminal justice system for pragmatic reasons. If anything, this 'system' is at the stage of defining itself and its reach altogether. While it is wholly rational and indeed reasonable that national prosecutors accept limitations to their work as a given in the current atmosphere of resource scarcity (and indeed as prescribed to them by their respective system contexts), it is legitimate to suggest a different perspective for the EU. It is submitted, for example, that the EU must not accept national practitioners' view that what they are doing (e.g. in relation to limiting the scope of cases) is correct. Any European criminal justice system is (and should be) set to deal only with a far more limited range of serious offences. Given this limitation, it is submitted that parallels to the workings of national criminal justice systems may be misleading. An independent decision must be made concerning which resources are made available to this system. Any priority setting to accommodate resource restrictions should be undertaken within the logic of the system when it is conceived or as necessary, not from the outset by those who would deny the existence of the system altogether.

Relating to the financial interests of the EU; the matter of immediate concern to an EPPO debate, the resource shortage argument is even less credible as such an office might conceivably pay for itself. Unquestionably there is a serious consideration as to the coherence (and legitimacy) of criminal justice systems in which crimes are

\footnotetext{
${ }^{85}$ As it is declared to be e.g. by the Stockholm Programme see: European Council [102; p.4]

${ }^{86}$ See e.g. Belgium - Finjaut [90] and Spain - Aebi/Balcells [60].

${ }^{87}$ Demonstrating that fundamentals like democratic legitimacy must also be interpreted differently in this context see von Bogdandy, A. [91; p.47 et seq.]. For an earlier take, e.g. Carter, C. and Scott, A. [92].
} 
prosecuted more comprehensively because these processes pay for themselves. ${ }^{88}$ If this office, however, forms the singular exception (see article 325 TFEU) discussed for the EU - i.e. is the sole supra-national criminal justice institution, then this is indeed a special case. It should perhaps not be burdened with the resource (and coherence) argument faced in national systems.

A separate debate (and one currently explicitly not sought by EU institutions as the Commission focuses upon the above) relates to serious cases of organised and transnational crime. Here too parallels to national cases may be misleading. The latest studies on prosecution policy indicate that the trend to drop cases does not extend to serious cases such as those of serious, organised crime but, above all, that such resource-saving measures are undertaken, to allow for full prosecution of precisely these types of crimes.[25]. Careful further research is necessary to compare European cases to equivalent national ones. Consideration should be given to the acceptability of disregarding aspects of such cases and their failure for legal or practical reasons. Indications are that most EU member states would view a case having trans-national dimensions, especially where these are considerable, as more and not less serious; as deserving of greater not lesser resources. ${ }^{89}$

As Europol and Eurojust interviewees are careful to point out, national practitioners currently make decisions (as best they can) on an incomplete informational basis. The latter themselves (and indeed judges when determining sentence) would view these type of offences differently if fully informed. Due to their severity, these crimes - carefully and thus restrictively defined, may well be the very ones normally lent priority at national level (at least in part); given greater resources in order to ensure comprehensive prosecution and punishment. The question whether this should not necessarily occur at the European level remains key. As precisely such relocation to the European level is, however, what is apparently required to discover the full extent of such crime, this provides one strong argument in favour of such development. ${ }^{90}$ This is a complex debate and should certainly be undertaken entirely separately to any debate concerning the development of mechanisms to protect the Union's own property interests. It is, however, also a debate concerning European cases; crimes facilitated by the EU and in which all EU citizens have an interest in prosecution. As such, these crimes are possibly a legitimate subject for a European criminal justice system and not merely national co-operation. ${ }^{91}$

\footnotetext{
${ }^{88}$ Hassemer [93; p.307] observes drily that security and effectiveness are preferred to freedom: "the foci of the new European criminal law lies in the strengthening of criminalisation and control, they are biases in the favour of victims (the institutional victims in particular, and in that context in particular the European institutions and there in particular those victims' interests which relate to assets)."

89 Thus e.g. the Council's steadily intensifying reference of such matters to Eurojust and Europol which goes considerably with each reform of their respective legal bases. The informational analysis now expected of them (see supra p. 573) inevitably means that the resources these institutions have to devote to such matters are increased.

90 And indeed the member states have decided pro-development on this issue in relation to Europol's tasks and powers with the new Decision increasing the Agency's activities in relation to serious trans-national and organised crime.

${ }^{91}$ In this regard, note that the EuroNEEDS interviews featured 14 national prosecutorial interviewees who claim to be forced to reduce the scope of cases due to a lack of co-operation from other member states. Also the 5 further interviewees who report having to do the same because jurisdictional competence is not sufficiently regulated between member states.
} 
Ultimately these debates may be viewed as two different sides of one coin; a European criminal justice system. Unless developments at the supra-national level are restricted to a singular anomaly; an exceptional area i.e. protecting the financial interests of the European Union, serious consideration of issues such as coherence and the development of a genuine system is urgently needed.

Even if an EPPO is created solely to prosecute fraud against the EU budget, corruption by EU employees, etc., its existence will have effects and highlight lacuna. The creation of just one body for a very specific purpose does not leave it immune to the issues faced in general criminal justice systems. Accountability, co-operation with other agencies and the question of powers must also be addressed. Furthermore, the presence of an EPP will only serve to highlight the crimes she has not been given power over which touch a European public interest. Protection of the Euro is a particularly obvious example. This is a development closely associated with the European Union but it is not a matter of its financial interests. Protection of the Euro falls to the member states who can call upon the support of European agencies like Europol. The problem is that the Euro naturally also requires protection beyond the borders of the Union. If counterfeit Euro banknotes are produced in e.g. South America, the entire Eurozone at least has an interest in seeing the counterfeiters prosecuted. It lacks a prosecutor, however. Such mismatches between the interests of the European public as such will be highlighted by a sectoral EPPO; it would be as well to consider them systematically in the course of the coming debate.

None of this changes the fact that in most European cases, there are member states who have jurisdiction to prosecute. The principle of subsidiarity requires the Union only to become active when the member states cannot. If however, the Union is better placed, or indeed simply permanently better resourced than the member states as well as more willing to prosecute criminal phenomena no one denies should be prosecuted, it seems illegitimate for the member states to block European development with the argument that they could assume this task. This is particularly true when their past behaviour, resource situations and the priorities set as a result speak only for the conclusion that they will not do so.

\section{Conclusion}

The EuroNEEDs study demonstrates that criminal justice practitioners working on, for and with the European level have specific needs. The broader study results illustrate steps taken so far as assisting them in overcoming a number of hurdles and indicating that the situation will continue to improve. This appears in no small part to be due to the dedication of practitioners working in all settings in which these cases are currently handled. Clarity as to which mechanisms practitioners should use or turn to in which situations would doubtlessly further improve the situation.

The study, however, also highlights deficits: the European perspective is not as discernible as it should be even to experienced practitioners. Cases cannot be tackled as they should be and are inadequately investigated. Furthermore, they are frequently subject to incomplete prosecution at a level viewed as unacceptable by a majority of 
study interviewees. The practitioners interviewed in the course of the study indicate that European cases see practitioners on many levels still facing clear limitations in their ability to tackle these successfully. It is hoped that this study will contribute to the debate surrounding these topics perhaps assisting the identification of the scope of action which needs to be taken and the needs which should be met via considered action.

There can be little doubt, however, that action is required. On the one hand sufficient information about European cases (phenomenon, behaviour, suspected persons and organisations) must be brought together to ensure the full dimensions of these cases are apparent to the practitioners investigating, prosecuting and adjudicating them. It is important that a practitioner network of some kind work together with a common sense of purpose to gather evidence. Within that network, the practitioner who takes ownership of the case must be sufficiently involved in all investigative actions in order to guide the investigation to maximum effect. Clearly this presupposes the existence of an investigator who takes ownership of European cases. To ensure comprehensive investigations of European cases, this must mean any idea that cases can be legitimately reduced to dimensions of national interest must be effectively countered. In other words a policy of European criminal justice is required. These arguments cannot but be seen to support the idea of an EPPO working within a clearly defined remit.

Given the inadequacy of the status quo indicated by practitioners who deal with such cases and the severity of crimes being discussed, it is surely uncontroversial to call for provision to be made for either comprehensive prosecution of such offences or rules to be set up to indicate Europe-wide prosecution parameters in accordance to which such cases are uniformly to be prosecuted. Investigations must then serve that end. Should only a selective investigation and prosecution of European cases be possible (this will depend upon the extent of crime and the resources dedicated to investigating and prosecuting them), a European criminal justice policy relating to such crime is necessary. The pattern of ad hoc measures of the past must be discarded in favour of coherence. ${ }^{92}$ In relation to financial crimes the Commission took an initial step in this direction with its communication of 2011 [26]. How this dialogue will develop remains to be seen. Any criminal policy setting at the supra-national level clearly brings a new basket of governance (legitimacy and accountability) issues with it. In relation to the types of crime described as trans-national in this paper this is yet another matter. The discussion led at the European level, often referring to organised crime is reported as marked by two influences: some seeing this as an area for co-operation whilst others see the need for harmonisation and supra-national institutionalisation. ${ }^{93}$ The fundamental decision will have to be made as to whether these are European cases and any consequences: institutional and policy-setting, based upon that.

The problem is, of course, that countless issues attach to any such development. Previous suggestions for an EPPO have consistently been met with criticism that the creation of an institution prior to harmonised law is illogical. ${ }^{94}$ With the suggested Directive for the protection of the financial interests of the European Union, the

\footnotetext{
92 For brief commentary upon the lack of policy in relation to criminalisation see Klip [94; p. 203].

93 See e.g. Moran Martinez [95; p.109] who describes the creation of Eurojust as a compromised between these two positions "for some Eurojust was the beginning, for others the end result." On the need to resolve this see Lopes de la Motta, J.L. [96; p.65].

${ }^{94}$ See e.g. Ambos [97, p.560].
} 
Commission has taken a first step in the financial interests context to provide for this broader context in this specific field.

Any bundling of European prosecutorial power bears incredible potential and cannot take place without securing its transparency, accountability and potential submission to judicial review on behalf of any person affected by them. Without particular provision for the defence - which admittedly harbours its own problems [27] - such developments would represent an unacceptable expansion of "state" or governance power.

There are indications that the investigation and prosecution of European cases could potentially be improved organically via the path apparently adopted currently by many supra-national interviewees; gaining the trust of former colleagues in the member states for their new (supra-nationalised) role and then using their additional perspective to suggest action (often informally) to their colleagues in national criminal justice systems. If this path is chosen, it must be clear that a law enforcement gap is accepted for the foreseeable future even for the serious offences discussed here. Such acceptance would appear to be in contradiction to action taken by the member states. Fairly recent Council decisions to enhance Europol and Eurojust's respective roles have signalled a determination to tackle serious trans-national and organised crime. It is the organs of the Union which currently highlight the inadequate protection of its financial interests ${ }^{95}$ but it defies imagination to picture the member states wishing to leave the Union vulnerable to fraud and corruption. ${ }^{96}$ Furthermore such an organic approach entrusts investigation and prosecution to national systems currently facing considerable resource barriers, if not walls.

The need for progress appears particularly acute for EU financial interests-related offences. National and supra-national interviewees have clearly identified a strong need for criminal justice professionals identifying with such cases, able to recognise and initiate their investigation as well as to ensure their full prosecution - even if they do not necessarily like the idea of the existence of this kind of figure at the supranational level. ${ }^{97}$

A detailed exploration of the principle of subsidiarity and what it means cannot be delivered within the context of this paper. ${ }^{98}$ Any debate relating to the creation of an EPPO will no doubt be marked, as were the EuroNEEDS interviews, by suggestions that the situation be improved by better utilization of current mechanisms and that further work at member state level could deliver progress. This is certainly true. The

\footnotetext{
$\overline{95}$ In addition see also the strong statements by the Committee on Budgetary Control of the European Parliament (known as Cocobu) made as commentary upon annual reports on the protection of the financial interests of the EU[98; p.2]. See also the concerns expressed by the European Parliament [99].

96 And indeed Hecker speaks of unanimous agreement that the Union's financial interest must be protected by the criminal law - see $[81 ; \mathrm{p} .496]$.

97 An EPPO as envisaged by article 86(2) TFEU, i.e. for the financial interests only, was greeted as a plausible model with which to test the potential of dovetailing such an institution with national prosecution services by a leading German prosecutor in 2002 - see Frank, C. [100; p.210].

${ }^{98}$ For a sceptical summary see Hassemer, W. [93; p.315]. He reports that German experience testifies to a higher governance/federal level enabled to seize any power it wishes. On the importance of exploring alternative avenues such as prevention through design (of subsidy programmes) see, e.g. Saetzger, A. [85; p.138] - drawing upon conclusions of the European Court of Auditors.
} 
heart of the debate over establishing an EPPO should be whether such a set up can improve the protection of the financial interests of the EU significantly better than alternatives. ${ }^{99}$ The EuroNEEDs study results indicate significant aspects for which this is likely true. Above all an EPPO's raison d'etre would be the "ownership" of cases as European. Comprehensive understanding of criminal activity and prosecution proportionate to it must come naturally to such a figure. Otherwise it would be devoid of meaning. Given that these aspects are the key features currently lacking, much speaks for an EPPO with adequate provision being made to ensure it has the requisite knowledge and capacity. Although many experts working on the national level oppose developments such as the establishment of an EPPO, a very significant proportion of their colleagues there, as well as those now working in the supra-nationalised institutional setting, view this as the only realistic means to progress; naturally only IF correctly structured. How a functioning EPPO can be created constitutes the basis of the next necessary discussion of potential and pitfalls.

Acknowledgment Thanks are due to John Baldwin, John Winterdyk and Lutz Roth for their comments on earlier drafts of this paper. Thanks are due also to Mr. Sam J. Cole for his assistance and to Ms Sarah Schultz whose excellent support during my time at the Max Planck Institute still assists me today. Responsibility for any mistakes rests, as always, with the author alone.

Open Access This article is distributed under the terms of the Creative Commons Attribution License which permits any use, distribution, and reproduction in any medium, provided the original author(s) and the source are credited.

\section{References}

1. Council Framework Decision of 15 March 2001 on the standing of victims in criminal proceedings (2001/220/JHA).

2. Council Framework Decision of 13 June 2002 on combating terrorism (2002/475/JHA).

3. Council Framework Decision of 24 October 2008 on the fight against organised crime. (2008/841/ JHA) L-300/42

4. European Parliament (2011). Directive 2011/36/EU of the European Parliament and of the Council of 5 April 2011 on preventing and combating trafficking in human beings and protecting its victims, and replacing Council Framework Decision 2002/629/JHA.

5. House of Lords, Select Committee on the European Communities, Session 1998-99, 9th Report, Prosecuting fraud on the Communities' finances - the Corpus Juris, HL Paper 62; online via the UK Parliament home page at www.parliament.uk.

6. Robledo, A., \& Cajani, F. (2009). Public prosecution office Milano Courtroom-Italy, In Policy Department on Budgetary Affairs: Committee on Budgetary Control-the follow-up of the European Anti-Fraud Office's (OLAF) administrative investigations in Member States, 19 February 2009. 25-27.

7. Jehle, J.-M., \& Wade, M. L. (Eds.) (2006). Coping with overloaded criminal justice systems-the rise of prosecutorial power (Springer).

8. COM (2001). 715 final. Green Book on the Protection of the Financial Interests of the Community and the establishment of a European Prosecutor. Brussels 11.12.2001.

9. Wade, M. L., \& Jehle, J. M. (Eds.) (2008). 'Prosecution and diversion within the criminal justice systems in Europe'. European Journal on Criminal Policy and Research 14(2-3).

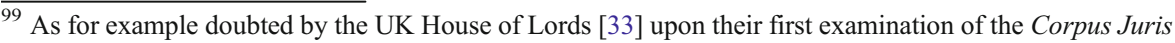
project.
} 
10. Schünemann, B. (2004). Fortschritte und Fehltritte in der Strafrechtspflege der EU, Goltdammer's Archiv für Strafrecht (GA), pp 193-209.

11. Tiedemann, K. (Ed.). (2002). Wirtschaftsstrafrecht in der Europäischen Union. Köln/Berlin/Bonn/ München: Carl Heymanns Verlag.

12. Council Framework Decision of 13 June 2002 on the European arrest warrant and the surrender procedures between Member States-Statements made by certain Member States on the adoption of the Framework Decision (2002/584/JHA), OJ L 190/1, 18.07.2002.

13. Council Framework Decision of 22 July 2003 on the execution in the European Union of orders freezing property or evidence. (2003/577/JHA) OJ 2003 1-196/45.

14. Council Framework Decision of 22 October 2004 laying down minimum provisions on the constituent elements of criminal acts and penalties in the field of illicit drug trafficking. (2004/757/JHA) OJ 2004 L-335/8.

15. European Council (2010). Notices from the European Union Institutions, Bodies, Offices and Agencies. European Council. The Stockholm Programme-an open and secure Europe Serving and Protecting Citizens (2010/C 115/01) O.J. 4.5.2010. C 115/1.

16. Espina Ramos, J. A. I., \& Carbajosa, V. (2009). The future European Public Prosecutor's office, Boletín del Estado. Madrid: Ministerio de Justicia.

17. Barnard, C. (2010). "The substantive law of the European Union-the four freedoms". OUP.

18. Carrera, S. (2012). An Assessment of the Commission's 2011 Shengen Government Package: Preventing abuse by EU Member States of freedom of movement? Centre for European Policy Studies, No47/March 2012. 1-28.

19. Initiative of the Kingdom of Belgium, the Republic of Bulgaria, the Republic of Estonia, the Kingdom of Spain, the Republic of Austria, the Republic of Slovenia and the Kingdom of Sweden for a Directive of the European Parliament and of the Council regarding the European Investigation Order in criminal matters Explanatory Memorandum 2010/C 165/02, Official Journal C 165, 24/06/2010 P. 0022 - 0039).

20. Council Decision 2009/426/JHA of 16 December 2008 on the strengthening of Eurojust and amending Decision 2002/187/JHA setting up Eurojust with a view to reinforcing the fight against serious crime L-138/14.

21. Council Decision of 6 April 2009 establishing the European Police Office (Europol) (2009/371/JHA) L-121/37.

22. COM (2012). 363/2. Proposal for a Directive of the European Parliament and of the Council on the fight against fraud to the Union's financial interests by means of criminal law. Brussels XXX.

23. Wade (2011). EuroNEEDS - determining the needs of and the need for a European criminal justice system-preliminary report, available online at: <http://www.mpicc.de/ww/en/prs/forschung/forschungsarbeit/strafrecht/euroneeds.htm.

24. COM (2003). 12 final. Follow up report on the Green Paper on the Criminal-Law protection of the financial interests of the Community and the establishment of a European Prosecutor. Brussels 19.3.2003.

25. Illuminati, G. (2004). 'The criminal justice system in Italy'. In U. Sieber, M. Wade. Structures for European Criminal Justice, Duencker and Humblot, vol. 3. 2013. In print.

26. COM (2011). 573 final. Communication from the Commission to the European Parliament, the Council, the European Economic and Social Committee and the Committee of the Regions-towards an EU Criminal Policy: Ensuring the effective implementation of EU policies through criminal law. Brussels, 20.9.2011.

27. Wade (2013). The defence and the legitimacy of European criminal justice. Journal of European Criminal Law. In print.

28. Delmas-Marty, M. (Ed.) (1998). Corpus Juris der strafrechtlichen Regelungen zum Schutz der finanziellen Interessen der Europäischen Union. Köln/Berlin/Bonn/München.

29. Spencer, J. (2012). Who's afraid of the big, bad European Public Prosecutor. Cambridge Yearbook of European Legal Studies. In press and on file with author.

30. Herlin-Karnell, E. (2008). The Lisbon Treaty and the Area of Criminal Law and Justice, Sieps European Policy Analysis, Issue 3-2008.

31. Van den Wyngaert, C. (2004). Eurojust and the European Public Prosecutor in the Corpus Juris Model: Water and fire?. In N. Walker (2004), Europe's Area of Freedom Security and Justice (pp 201-239). (OUP).

32. Zwiers, M. (2011). The European public prosecutor's office-analysis of a multilevel criminal justice system, Intersentia, 2011.

33. House of Lords Select Committee on the European Union (2003-04). Twenty-third report.

34. House of Lords Select Committee on European Scrutiny (2002). Twenty-sixth report. 
35. Wade, M. (2013). "Part III-present national criminal justice structures". In U. Sieber, M. Wade (2013), "Structures of European Criminal Justice-volume 1: Central findings" Duncker and Humblot. In print.

36. Vervaele, J. (2009). From Eurojust to the European Prosecution Service in the European Judicial Area. The beginning of a European Criminal Procedural Law. In J. A. E. Ramos, V. I. Carbajosa. 'The future European Public Prosecutor's Office, Fiscalia General del Estado, 2009' (pp 125-162)

37. OLAF (2007). Report of the European Anti-Fraud Office, Summary Version, Eighth Activity Report for the period 1 January 2007 to 31 December 2007, Luxembourg 2008.

38. House of Lords Select Committee F 9th Report 2006-2007 Schengen Information System II: Report with Evidence, at 7-8, available at http:/www.publications.parliament.uk/pa/ld200607/ldselect/ldeucom/ 49/49.pdf.

39. Wade, M. L. (2009). The future of borders. In J. A. Winterdyk \& K. W. Sundberg (Eds.), "Border Security in the Al-Qaeda Era", Boca Raton [et al.] (pp. 349-364). New York: CRC Press.

40. Roma, M. (2004). A European Public Prosecutor would be a dangerous distraction, CER Bulletin, Issue 35, April/May. Available at <http://www.cer.org.uk/publications/archive/bulletin-article/2004/ european-public-prosecutor-would-be-dangerous-distraction> Date accessed 19/09/2012.

41. Vervaele, J. A. E. (2008a). 'Future of European Criminal Law and Harmonization of Criminal Law Enforcement' lecture at the Max Planck Institute for Foreign and International Criminal Law, 8th March 2008 .

42. Bundesrat (2011). Beschluss des Bundesrates, Drucksache 334/11 (the position of the Bundesrat on the Communication from the Commission on the Protection of the financial interests of the European Union by criminal law and by administrative investigations (Berlin, 8 July 2011)) available at: http:// www.bundesrat.de/cln_152/SharedDocs/Drucksachen/2011/0301-400/334-11_28B_29,templateId= raw,property=publicationFile.pdf/334-11.

43. White, S. (2002). The European prosecutor: extension of eurojust or "prolongation" of the corpus juris proposals? In G. de Kerchove, A. Weyembergh (2002), L'espace penal europeen: Enjeux et perspectives (pp 47-53). University of Brussels.

44. Tampere European Council 15 and 16 October 1999-presidency conclusions, pp 33-37.

45. COM (2011). 175 final. Report from the Commission to the European Parliament and the Council on the implementation since 2007 of the Council Framework Decision of 13 June 2002 on the European arrest warrant and the surrender procedures between Member States. Brussels 11.4.2011.

46. Suominen, A. (2008). The past, present and future of Eurojust. Maastricht Journal of European and Comparative Law, 15(2), 217-239.

47. Xanthaki, H. (2010). What is EU fraud? and can OLAF really combat it? Journal of Financial Crime, 17(1), 133-151.

48. House of Lords European Union Committee, The Treaty of Lisbon: An Impact Assessment, pp 142-143.

49. Mitsilegas, V. (2009). EU criminal law: Modern studies in EU criminal law. Hart.

50. Hodgson, J. (2005). French criminal justice: A comparative account of the investigation and prosecution of crime in France. Hart.

51. Tak, P. (Ed.). (2004). Tasks and powers of the prosecution services in the EU Member States. Nijmegen: Wolf.

52. Tak, P. (Ed.). (2005). Tasks and powers of the prosecution services in the EU Member States volume II. Nijmegen: Wolf.

53. Lewis, C. (2006). 'The prosecution service function within the English Criminal justice system'. In J.M. Jehle, M. L. Wade (Eds.), Coping with overloaded criminal justice systems-the rise of prosecutorial power. Springer (pp 151-184).

54. Aubusson de Cavarlay, B. (2006). 'The prosecution service function within the French criminal justice system'. In J.-M. Jehle, M. L. Wade (Eds.), Coping with overloaded criminal justice systems -the rise of prosecutorial power. Springer (pp 185-206).

55. Elsner, B., \& Peters, J. (2006). 'The prosecution service function within the German criminal justice system. In J.-M. Jehle, M. L. Wade (Eds.), Coping with overloaded criminal justice systems-the rise of prosecutorial power. Springer (pp 207-236).

56. Blom, M., \& Smit, P. (2006). 'The prosecution service function within the Dutch criminal justice system'. In J.-M. Jehle, M. L. Wade (Eds.), Coping with overloaded criminal justice systems-the rise of prosecutorial power. Springer (pp 237-256).

57. Zila, J. (2006). 'The prosecution service function within the Swedish criminal justice system'. In J.-M. Jehle, M. L. Wade (Eds.), Coping with overloaded criminal justice systems-the rise of prosecutorial power. Springer (pp 285-314). 
58. Turković, K. (2008). The prosecution service function within the Croatian criminal justice system'. In M. Wade, J. M. Jehle (Eds.), 'Prosecution and diversion within the criminal justice systems in Europe' 14(2-3) European Journal on Criminal Policy and Research (pp 263-288).

59. Róth, E. (2008). 'The prosecution service function within the Hungarian criminal justice system'. In M. Wade, J. M. Jehle (Eds.), 'Prosecution and diversion within the criminal justice systems in Europe' 14(2-3) European Journal on Criminal Policy and Research (pp 289-310).

60. Aebi, M. F., \& Balcells, M. (2008). 'The prosecution service function within the Spanish criminal justice system'. In M. Wade, J. M. Jehle (Eds.), 'Prosecution and diversion within the criminal justice systems in Europe' 14(2-3) European Journal on Criminal Policy and Research (pp 311-332).

61. Gilliéron, G., \& Killias, M. (2008). 'The prosecution service function within the Swiss criminal justice system'. In M. Wade, J. M. Jehle (Eds.), 'Prosecution and diversion within the criminal justice systems in Europe' 14(2-3) European Journal on Criminal Policy and Research 2008, 333-352.

62. Hakeri, H. (2008). 'The prosecution service function within the Turkish criminal justice system'. In M. Wade, J. M. Jehle (Eds.), 'Prosecution and diversion within the criminal justice systems in Europe' 14(2-3) European Journal on Criminal Policy and Research 2008, 353-368.

63. Wade (2006). The power to decide-prosecutorial control, diversion and punishment in European criminal justice systems today. In J.-M. Jehle, M. Wade. Coping with overloaded criminal justice systems, Springer (pp 27-126).

64. Donoghue, B. (2008). European public prosecutor: Will it happen? speech at the Law Society Annual Conference, Budapest, March 2008.

65. COM (2011). 293 final. Communication from the Commission to the European Parliament, the Council, the European Economic and Social Committee and the Committee of the Regions on the protection of the financial interests of the European Union by criminal law and by administrative investigations. An integrated policy to safeguard taxpayers' money. Brussels. 26.5.2011.

66. OLAF (2012). Report of the European Anti-Fraud Office 2011. <Available at http://ec.europa.eu/anti_ fraud/documents/reports-olaf/2011/olaf_report_2011.pdf $>$ accessed on 17/09/2012.

67. Savona, E. (2006). 'Measuring organised crime: An international perspective' in UNODC forum on Crime and Society, Special Issue, "improving knowledge on crime: towards better data". 5(1)\& (2), 21-34.

68. Van Duyne, P. C. (2010). 'Organised crime (threat) as a policy challenge: A tautology. In 'Organised crime, civil society and the policy process' Conference Proceedings, Risk Monitor Foundation May 2010.

69. Jehle, J.-M. (2006). The "function of public prosecution within the criminal justice system-aim, approach and outcome of a European Comparative Study”. In J.-M. Jehle, M. L. Wade (Eds.) (2006), Coping with overloaded criminal justice systems - the rise of prosecutorial power. Springer.

70. Wade, M. (2008). The Januses of Justice-how prosecutors define the kind of justice done across Europe. European Journal of Crime, Criminal Law and Criminal Justice, 16(4), 433-455.

71. Luna, E., \& Wade, M. (2010). Prosecutors as judges. In Washington and Lee Law Review. Vol 67/Issue 42010 (pp 1413-1532).

72. Model Rules for the European Public Prosecutor available at http:/www.eppo-project.eu/index.php/ EU-model-rules/english.

73. COM (2005). 583 final/2. Communication from the Commission to the European Parliament and the Council on the implications of the Court's judgment of 13 September 2005 (Case C-176/03 Commission v Council) Brussels, 24.11.2005.

74. Council Decision of 28 February 2002 setting up Eurojust with a view to reinforcing the fight against serious crime (2002/187/JHA), OJ L 63/1, 06.03.2002.

75. Wade, M. (2013). "Part II-Institutions and Quasi-Institutions of Current European Criminal Justice Structures" in Sieber/Wade Structures for European Criminal Justice, Duncker and Humblot, 2013. In print.

76. Neuhann, F. (2008/2009). Europa-Paradies fuer Betrueger? in Jahrbuch fuer Oeffentliche Sicherheit, 533-541.

77. Xanthaki, H., White, S., Stefanou, C. (2011). OLAF at the crossroads-action against EU fraud. (Hart).

78. Ashworth, A., \& Roberts, J. (2012). 'Sentencing: Theory, principle and practice'. In M. Maguire, R. Morgan, R. Reiner (Eds.), The Oxford Handbook of Criminology (OUP) (pp 866-894).

79. Vervaele, J. (2008). The shaping and reshaping of Eurojust and OLAF in eucrim 3-4/2008.

80. Braum, S. (2002). Europaeisches Strafrecht im administrativen Rechtsstil in ZRP 12/2002. 508-514.

81. Hecker, B. (2010). Europaeisches Strafrecht, 3rd ed. Springer.

82. Radtke, H. (2004). Der Europaeische Staatsanwalt-Ein Modell fuer Strafverfolgung in Europa mit Zukunft, in GA pp 1-21. 
83. Costa, J. (2004). Eurojust vis-à-vis the European Public Prosecutor. In J. Apap (2004), Justice and home affairs in the EU. Edward Elgar Press.

84. Brady, H. (2010). Does the EU need a public prosecutor? CER Bulletin, Issue 70, February/March. $<$ http://www.cer.org.uk/publications/archive/bulletin-article/2010/does-eu-need-public-prosecutor> date accessed 20/09/12.

85. Sätzger, A. (2003). Gefahren fuer eine effective Verteidigung im geplannten europaeischen Verfahrensrecht, in StV 2/2003, pp 137-142.

86. White, S. (2010). EU anti-fraud enforcement: overcoming obstacles. Journal of Financial Crime, 17(1), 81-99.

87. Suhr, O. (2009). Die polizeiliche und justizielle Zusammenarbeit in Strafsachen nach dem "Lissabon"-Urteils des Bundesverfassungsgerichts in ZEuS, 4/2009, pp 687-715.

88. Nieto, A., Wade, M., Morales, M. (2012). "Prosecutors in federal structures"-transversal report in Ligetti, K. "Criminal Investigations in the EU” Hart, 2012. In print.

89. Sätzger, A. (2010). Internationales und Europaeisches Strafrecht (4th ed.). Baden Baden: Nomos.

90. Finjaut, C. (2008). Introduction in EJCCJ\&CL 2.

91. von Bogdandy, A. (2010). Founding principles. In A von Bogdandy, J. Bast (2010), Principles of European Constitutional Law (2nd ed.), (pp 11-54) Hart/C.H. Beck/Nomos.

92. Carter, C., \& Scott, A. (1998). Legitimacy and governance beyond the European Nation State: conceptualising governance in the European Union. European Law Journal, 4(4), 429445 .

93. Hassemer, W. (2004). Strafrecht in einem europaeischen Verfassungsvertrag in ZStW 116 (2004) 2, pp 304-319.

94. Klip, A. (2009). European Criminal Law. Intersentia.

95. Moran Martinez, R. A. (2009). Contribution to round table III. In J. A. Espina Ramos \& I. Vicente Carbajosa (Eds.), The future European Public Prosecutor's office, Boletín del Estado (pp. 106-116). Madrid: Ministerio de Justicia.

96. Lopes de la Motta, J. L. (2008). Eurojust - the heart of the future European Public Prosecutor's office in Eucrim 1-2/2008.

97. Ambos, K. (2011). Internationales Strafrecht, 3rd ed. Beck.

98. Cocobu Info (2011). Issue 3/2011 available at: http:/www.europarl.europa.eu/document/activities/ cont/201101/20110121ATT12212/20110121ATT12212EN.pdf (last download 24 August 2012).

99. European Parliament (2012). Resolution of 10 May 2012 on the protection of the European Union's financial interests-fight against fraud-annual report 2010 (2011/2154(INI) available at: http:// www.europarl.europa.eu/sides/getDoc.do?type=TA\&language=EN\&reference=P7-TA-2012-196.

100. Frank, C. (2002). Der Europaeische Staatsanwalt: ein denkbares Modell in DriZ.

101. Bulenda, T., Gruszczynska, B., Kremplewski, A., Sobota, P. (2006). 'The prosecution service function within the Polish criminal justice system'. In J.-M. Jehle, M. L. Wade (Eds.), Coping with overloaded criminal justice systems - the rise of prosecutorial power (Springer) (pp 257-284) Springer.

102. COM (2003). 128 final. Follow-up report on the Green Paper on the criminal-law protection of the financial interests of the Community and the establishment of a European Prosecutor. Brussels 19.3.2003.

103. COM (2007). 664 final. Communication on the Future of Eurojust and the European Judicial Network. Brussels 23.10.2007.

104. COM (2011). 135 final. Amended proposal for a Regulation of the European Parliament and of the Council amending Regulation (EC) No 1073/1999 concerning investigations conducted by the European Anti-fraud Office (OLAF) and repealing regulation.

105. Council Act of 29 May 2000 establishing in accordance with Article 34 of the Treaty on European Union the Convention on Mutual Legal Assistance in Criminal Matters between the Member States of the European Union OJ (2000/C197/01).

106. Council of the European Union Inter-institutional File: 2010/0817 (COD). Outcome of Proceedings of: Working Party on Cooperation in Criminal Matters. Subject: Initiative of the Kingdom of Belgium, the Republic of Bulgaria, the Republic of Estonia, the Kingdom of Spain, the Republic of Austria, the Republic of Slovenia and the Kingdom of Sweden for a Directive of the European Parliament and of the Council regarding the European Investigation Order in criminal matters- Preamble, forms and annex related to Article 29.1. COPEN 104.

107. Deiters, M. (2006). Legalitätsprinzip und Normgeltung. Tübingen: Mohr Siebeck.

108. European Commission Corpus Juris (2000). Available at $<$ http://ec.europa.eu/anti_fraud/documents/ fwk-green-paper-corpus/corpus_juris_en.pdf $>$ date accessed 24/10/2012.

109. Hecker, B. (2007). Europäisches Strafrecht, 2. Auflage. Berlin/Heidelberg/New York: Springer. 
110. Hofmann, M. (2006). Straftatbestände und Sanktionen zum Schutz der finanziellen Interessen der EU: Die Umsetzung der einschlägigen EU-Rechtsinstrumente in den Mitgliedstaaten. In Z. Đurđević (Ed.), Current issues in European Criminal Law and the protection of EU financial interests, Zagreb.

111. Ramos, J. A. E. Towards a European Public Prosecutor's office: The long and winding road. In A. Klip (Ed.), "Substantive criminal law of the European Union"(Maklu) (pp 15-34).

112. Tiedemann, K. Leipziger Kommentar zum StGB, §§ 223-263a, 11. Auflage 2000.

113. Wade, M. (2009). 'The European public prosecutor - the future of European criminal justice'. In F. Yenisey, U. Sieber (Eds.), Criminal law in the global risk society (pp 299-310) Bahcesehir Universitesi. 